\title{
FIRE RESISTANCE OF STEEL TUBULAR COLUMNS INFILLED WITH ULTRA-HIGH STRENGTH CONCRETE
}

\author{
X. Lyu ${ }^{1,2}$, G.P. Shu ${ }^{1,2, *}$, J.Y. Richard Liew ${ }^{3}$ and Er-F. Du ${ }^{1,2}$ \\ ${ }^{I}$ School of Civil Engineering, Southeast University, Nanjing 210096, China \\ ${ }^{2}$ Key Laboratory of C \& PC Structures, Ministry of Education, Southeast University, Nanjing 210096, China \\ *(Corresponding author: E-mail:ssp0818@vip.sina.com) \\ ${ }^{3}$ Department of Civil and Environmental Engineering, National University of Singapore, E1A-07-03, 1 Engineering \\ Drive 2, Singapore 117576, Singapore
}

Received: 12 May 2017; Revised: 4 August 2017; Accepted: 25 November 2017

\begin{abstract}
Ultra-high strength concrete filled steel tubular columns (UHSCFT) with compressive strength more than $100 \mathrm{MPa}$ are an attractive option for high-rise buildings and several such applications have been seen in modern construction around the world. The compressive strength of ultra-high performance concrete/cement composite could reach as high as $180 \mathrm{~N} / \mathrm{mm}^{2}$. This paper investigates the fire resistance of externally protected ultra-high strength concrete filled tubular columns exposed to the standard ISO fire. Numerical analyses were carried out using a general finite element analysis software and the results were validated against the test results in terms of heat distribution and thermal-mechanical behavior. Comparison with the test results showed a reasonable agreement with finite element results in terms of temperature prediction and load displacement behavior during the fire. Finally, based on the validated finite element model, further numerical investigations were carried to study the effects of fire protection thickness, load ratio, the strengths of concrete and steel, steel contribution ratio, relative slenderness ratio and the steel section diameter on the fire resistance of ultra-high strength concrete filled tube columns.
\end{abstract}

Keywords: Buckling resistance, column filled tube, thermal analysis, finite element analysis, fire resistance, ultra-high strength concrete

DOI: $10.18057 /$ IJASC.2018.14.3.8

\section{INTRODUCTION}

Steel tubular columns are commonly used in high-rise buildings because their load and fire resistance can be further enhanced by filling them with concrete (Lie and Chabot [1]; Tao et al. [2]; Zha et al. [3]). The main benefit of using concrete filled tubular columns is the increase of load bearing capacity without the need of additional formwork (Jamaluddin et al. [4]; Kang et al. [5]). The concrete core acts as heat sink to reduce the temperature of the steel tube when the composite column is subjected to fire (Xiao et al. [6]).Various types of concrete filling may be used in practice, including unreinforced concrete, steel bar reinforced concrete, and steel fiber reinforced concrete (Han et al. [7]; Fong et al. [8]; Xu et al. [9]). The infill concrete also enhances the steel tube's resistance to local buckling.

Studies on the fire resistance of steel tubular columns infilled with normal and high strength concrete have been carried out by several researchers (Wang and Young [10]; Yang et al. [11]; Liew and Xiong [12]; Li et al. [13]). Recent research focuses on the use of ultra-high strength concrete (UHSC) as infilling material to form concrete filled tubular members (CFTs) (Lee et al. [14]; Xiong and Liew [15]; Liew et al. [16]). Steel tubular members infilled with UHSC with compressive strength up to $180 \mathrm{~N} / \mathrm{mm}^{2}$ provide higher compression resistance and, therefore, smaller column size. Liew et al. [17 \& 19] have investigated the behavior of such columns in both ambient temperature and fire situations. 
Ultra-high strength concrete material is very brittle and has no post peak behavior after it is loaded beyond the maximum load. This is a serious drawback and limits its application in construction. However, when UHSC is used in concrete filled tubes, the confinement provided by the steel tube can improve the post-peak ductility of the ultra-high strength concrete depending on the steel contribution ratio as observed by Liew et al. [18] in the experimental studies.

This paper presents the nonlinear finite element analysis model to simulate the fire resistance of UHSC filled tubular columns exposed to the standard fire condition. The composite action between the steel and concrete has been considered in the numerical model. The column is subjected to axial compression followed by heating under standard ISO fire until failure. The analysis considers the influences of temperature on the strength and modulus of the UHSC material based on the test data from Xiong [19]. The accuracy of the numerical model is established by comparing the numerical results with test results. Finally, parametric studies are carried out to evaluate the effects of fire protection thickness, load ratio, strengths of concrete and steel, steel contribution ratio, column slenderness ratio and the steel section diameter on fire resistance of steel tubular columns infilled with UHSC. The findings are useful for the designer to derive cost-effective solutions in providing fire protection and determining the fire resistance performance of composite column.

\section{TEMPERATURE CALCULATION OF CONCRETE FILLED TUBULAR MEMBERS}

Experimental work on tubular beam-columns infilled with high strength and ultra-high strength concretes subjected to ISO standard fire have been carried out by Xiong [19]. The details of the test specimens are shown in Table 1. The test specimens for the analysis are taken from Xiong [Error! Bookmark not defined.]. All the columns are $3.81 \mathrm{~m}$ with $3.0 \mathrm{~m}$ long exposed to fire in the furnace, and the details are shown in Table 1 and Figures $1(\mathrm{a}) \& 1(\mathrm{~b})$. The prediction of the temperature field in the ultra-high strength concrete filled tubular column is based on the fire temperature in the furnace.

Table 1. Details of The UHSCFT Columns

\begin{tabular}{|c|c|c|c|c|c|c|c|}
\hline Specimen & $\begin{array}{c}\text { Diameter }(\mathrm{D}) \times \\
\text { thickness }\left(t_{\mathrm{s}}\right) \\
(\mathrm{mm} \times \mathrm{mm}) \\
\end{array}$ & $\begin{array}{l}\text { Steel yield } \\
\text { strength } \\
f_{\mathrm{y}}(\mathrm{MPa}) \\
\end{array}$ & $\begin{array}{c}\text { Steel Modulus } \\
\text { of Elasticity } \\
E_{\mathrm{a}}(\mathrm{GPa}) \\
\end{array}$ & $\begin{array}{c}\text { Concrete Cylinder } \\
\text { Strength } \\
f_{\mathrm{c}}(\mathrm{MPa}) \\
\end{array}$ & $\begin{array}{c}t_{\mathrm{p}}{ }^{*} \\
(\mathrm{~mm})\end{array}$ & $\delta^{*}$ & $\bar{\lambda}^{*}$ \\
\hline UCZ-1 & $219.1 \times 16$ & & & 161 & 5.9 & 0.50 & 1.01 \\
\hline UCZ-2 & $219.1 \times 16$ & 432 & 204 & 168 & 6.4 & 0.49 & 1.02 \\
\hline UCZ-3 & $219.1 \times 16$ & & & 164 & 8.1 & 0.49 & 1.02 \\
\hline UCZ-4 & $273 \times 16$ & 422 & 203 & 181 & 6.8 & 0.40 & 0.86 \\
\hline UCZ-5 & $273 \times 10$ & 418 & 201 & 180 & 8.6 & 0.28 & 0.94 \\
\hline
\end{tabular}

*Notes: $t_{\mathrm{p}}$ is thickness of fire protection. $\delta=A_{\mathrm{a}} f_{\mathrm{y}} /\left(A_{\mathrm{a}} f_{\mathrm{y}}+A_{\mathrm{c}} f_{\mathrm{c}}\right)$ is the steel contribution ratio. $\lambda$ is the relative slenderness.

The fire resistance of ultra-high strength concrete filled tubular (UHSCFT) column depends on the fire temperature to which the column is exposed, the temperature field in the column, the strength of the materials at elevated temperature and the member deformations during the fire exposure. Using the temperature-dependent thermal properties of the concrete and steel, the temperature history of the column can be obtained by solving the heat balance equation [20]. A two-dimensional nonlinear thermal analysis model for the UHSCFT column exposed to a fire on four sides is considered, with the assumption that no heat is flowing along the longitudinal axis [21-22]. The finite element simulations for both the heat transfer and structural analyses are conducted using the general finite element analysis package ABAQUS. 
One of the main ingredients in making UHSC is bauxite aggregate which has better fire resistance than the siliceous aggregate as use in normal strength concrete (NSC). The residual strength and the strength reduction factor of USHC are larger than those of NSC at elevated temperature. Furthermore, comparing UHSC with NSC, the strength reduction factor of UHSC is similar to NSC with calcareous aggregate, but higher than NSC with siliceous aggregate at temperature higher than $200^{\circ} \mathrm{C}$. In other words, the strength and elastic modulus of UHSC are reduced less than those of NSC at elevated temperature. However, explosive spalling behavior of UHSC was observed when it was heated up to $500^{\circ} \mathrm{C}$. But this can be prevented by adding polypropylene fibers $0.1 \%$ volume of concrete.

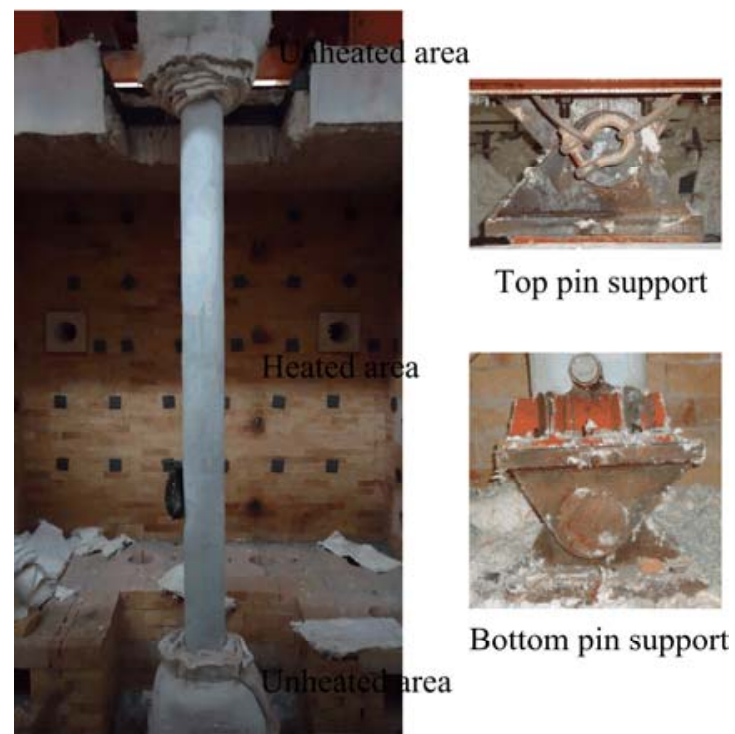

(a) Circle specimen in furnace

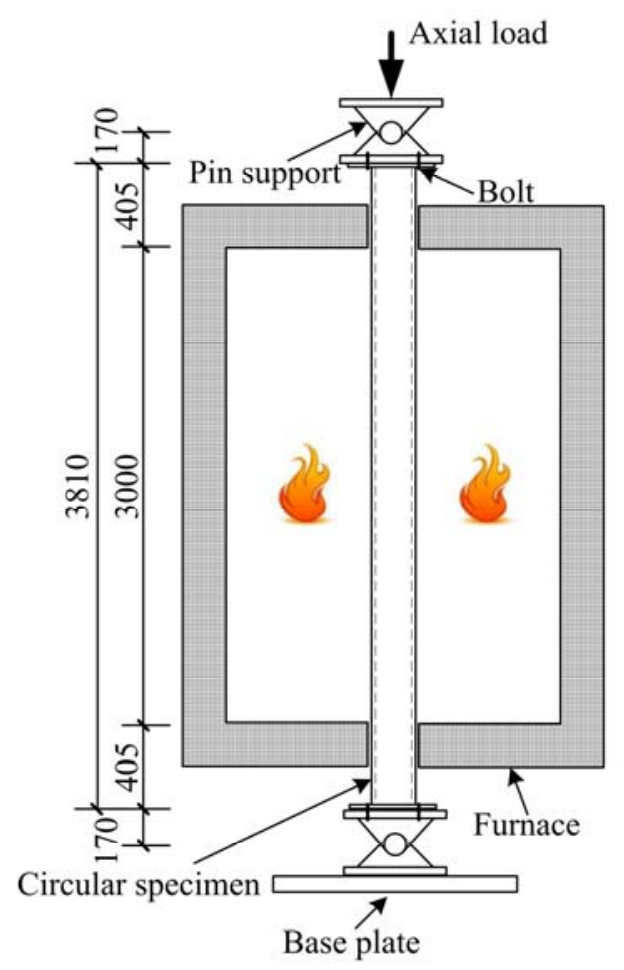

(b) Schematic of the experiment setup

Figure 1. Boundary Condition for Column Specimen in Test (Xiong [19])

\subsection{Thermal Properties of Ultra-High Strength Concrete (UHSC)}

The thermal properties include the thermal conductivity, specific heat, thermal expansion, and the mass loss of the material at elevated temperatures. There are three material models of thermal properties which are often adopted for the heat transfer calculations. One is the Lie's thermal model, the second one is the AIJ code model, and the third one is the Eurocode model. In this paper, the thermal model is based on the Eurocode model [23-24] which considers the effects of water in the concrete on density and specific heat. Generally, the lower limit of thermal conductivity is used for normal strength concrete (NSC), while the upper limit is considered for high strength concrete (HSC) and ultra-high strength concrete (UHSC). The moisture content is assumed to be $3 \%$ for NSC and HSC, whereas it is ignored for UHSC.

\subsection{Thermal Properties of Fire Protection Material}

In the fire tests reported in Xiong [19], the fire protection material was a mixture of Portland cement $(40 \%)$, perlite $(25 \%)$, vermiculite $(20 \%)$ and water $(15 \%)$ by weight. The thermal properties 
are assumed not to change with temperature. The thermal conductivity $=0.116 \mathrm{~W} / \mathrm{m} \cdot \mathrm{K}$, specific heat $=1010 \mathrm{~J} / \mathrm{kg} \cdot \mathrm{K}$ and density $=305 \mathrm{~kg} / \mathrm{m}^{3}$ are adopted based on the test data reported in Xiong [19].

\subsection{Thermal Analysis of Specimens}

The initial ambient temperature is set as $20^{\circ} \mathrm{C}$. In the thermal analysis, 4-node shell element (DS4) is adopted to model the steel tube and 8-node brick element (DC3D8) for the concrete core and the fire protection with three layers along its thickness. The heat convection and radiation are considered as boundary conditions in the thermal analysis as shown in Figures 2a-c. The height of specimen exposed to fire is $3.0 \mathrm{~m}$, while the height of specimen is $3.81 \mathrm{~m}$. The composite column is subjected to uniform heating (close to an ISO standard fire) from the surrounding air in the furnace during the entire heating process.

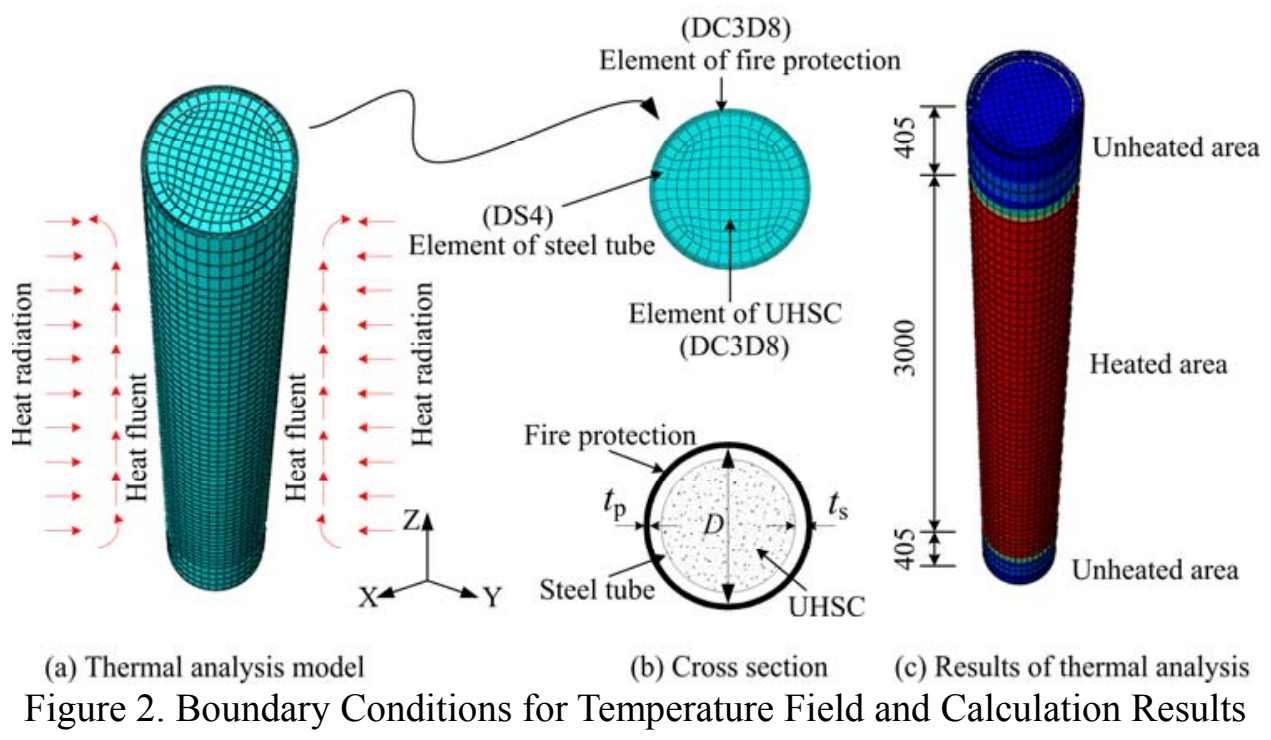

\subsection{Comparison of Predicted Results with Tests}

There are three measured points in the UHSCFT column. Point 1 is at the centre of column cross-section, point 2 is at the position of $r / 2$ ( $r$ is radius of concrete core) and Point 3 is at the edge of the concrete core. The predicted temperatures based on the finite element analyses are compared with the measured temperatures from the tests, as shown in Figure 3. The furnace temperature was measured and plotted in Figures 3 (a)-(e).

For specimen UCZ-1, the measured temperature at point 2 compared well with the predicted results. The mean error between the predicted temperature and measured temperature is less than $5 \%$, what's more, with the temperature increasing, the value of the error becomes decreasing. The other two thermocouples at points 1 and 3 did not record any readings as they were damaged during the preparation of the test specimen. For specimen UCZ-2, the mean errors between the predicted temperature and measured temperature for points 1,2 and 3 are less than $5 \%$, although the error is a little big for point1 after exposing to fire 90 minutes. For specimens UCZ-3 and UCZ-5, the comparisons showed that the predicted temperatures were in reasonable agreement with the measured values. As shown in Figure $3 \mathrm{c}$, the mean errors between the predicted temperature and measured temperature for points 1 and 2 are less than $4 \%$, although the mean error is about $12 \%$ for point 3. For specimen UCZ-5, the mean errors between the predicted temperature and measured temperature for points 1 and 3 are less than $6 \%$, although the mean error is about $15 \%$ for point 2 . 
The same reason was applied to the measure point 3 of UCZ-4, while the predicted temperature at points 1 and 2 are acceptable compared with the measured values.

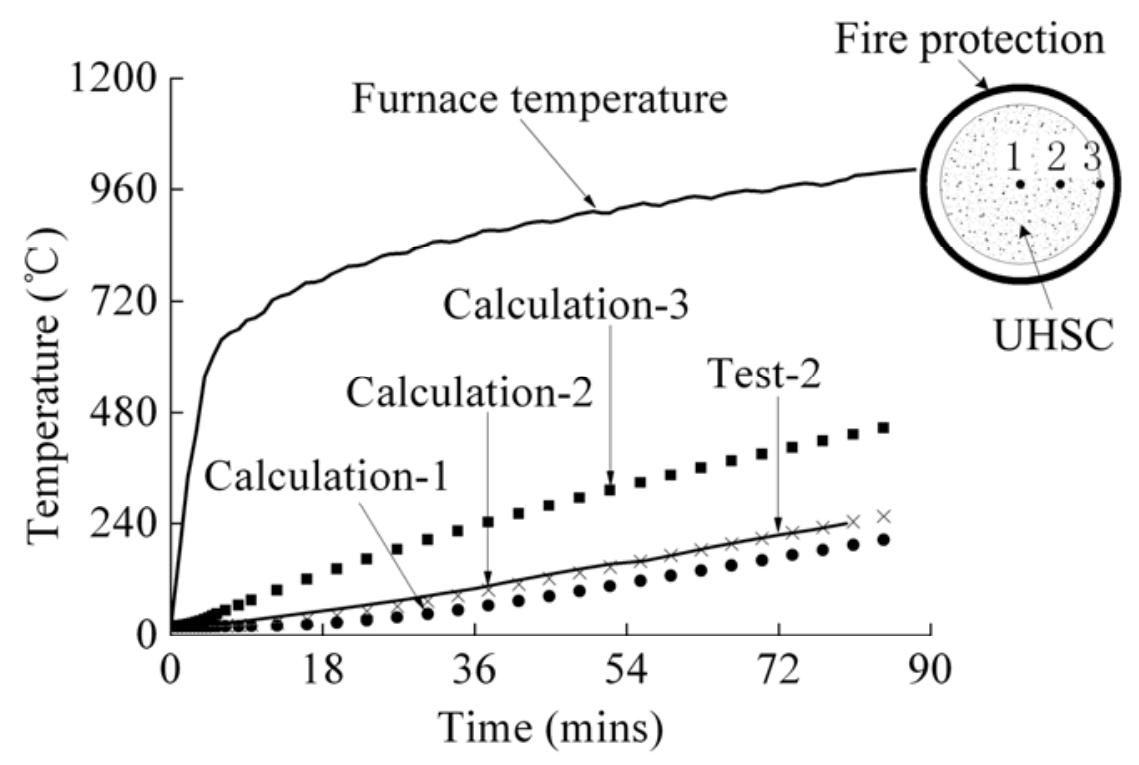

(a) Specimen UCZ-1

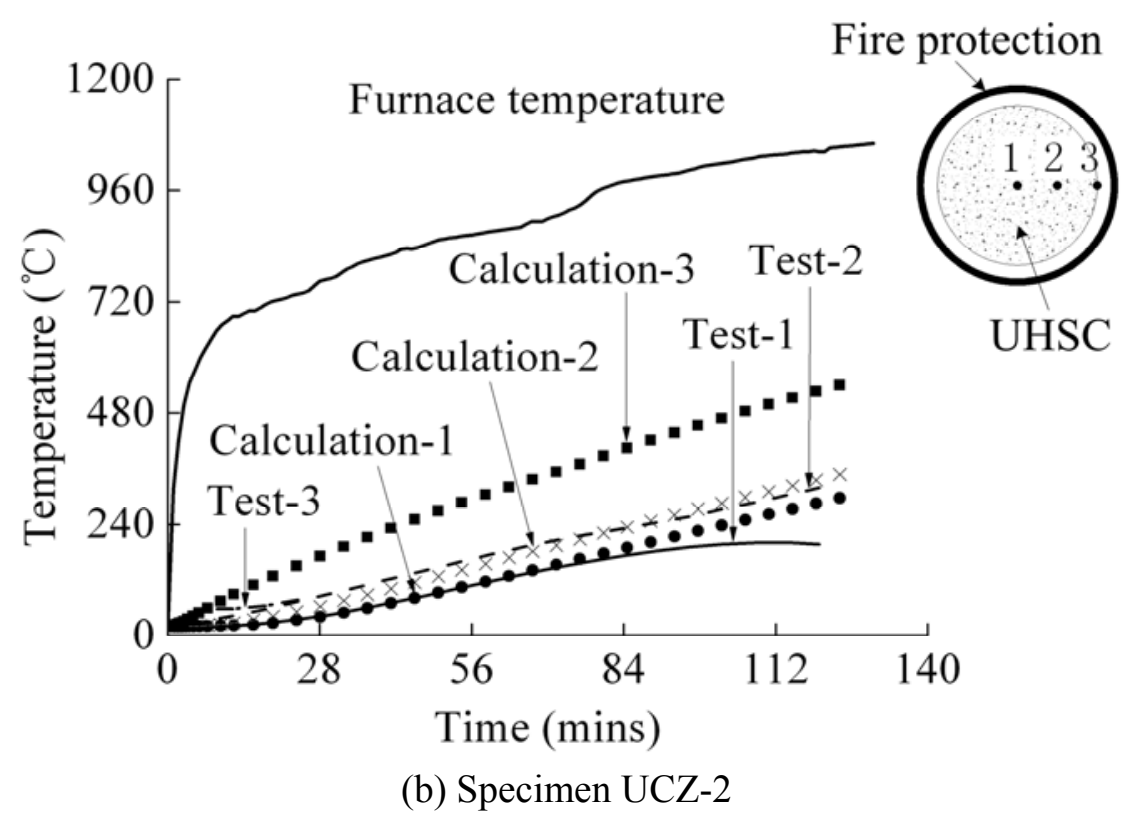


Fire protection

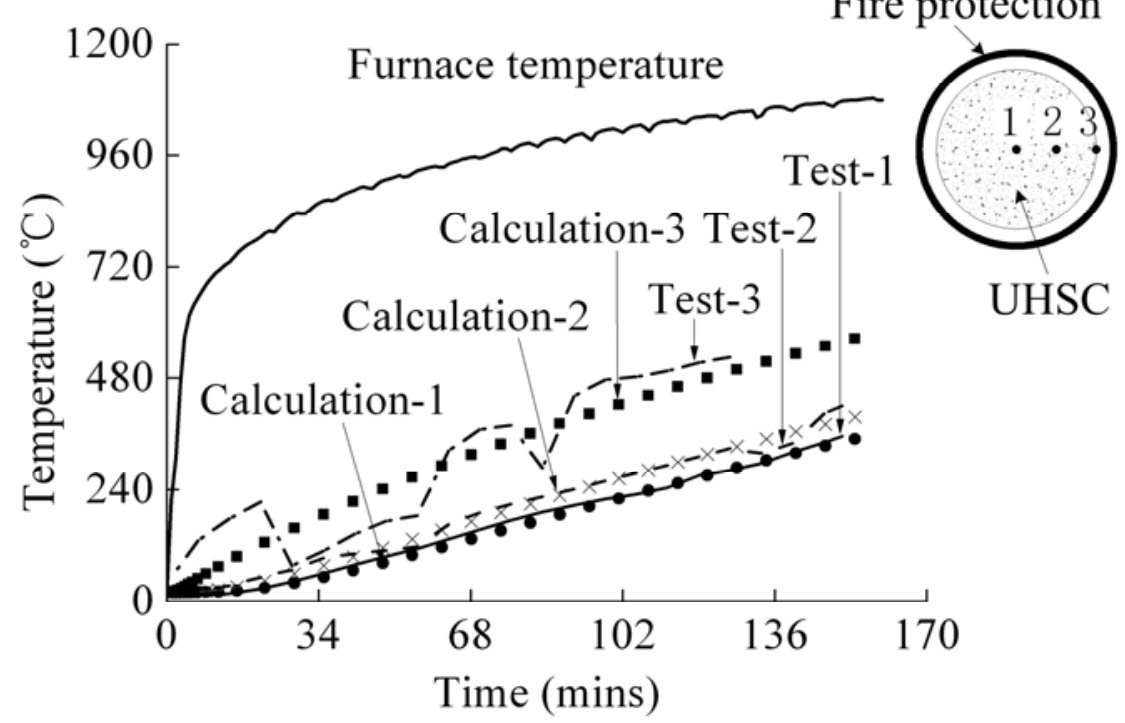

(c) Specimen UCZ-3

Fire protection

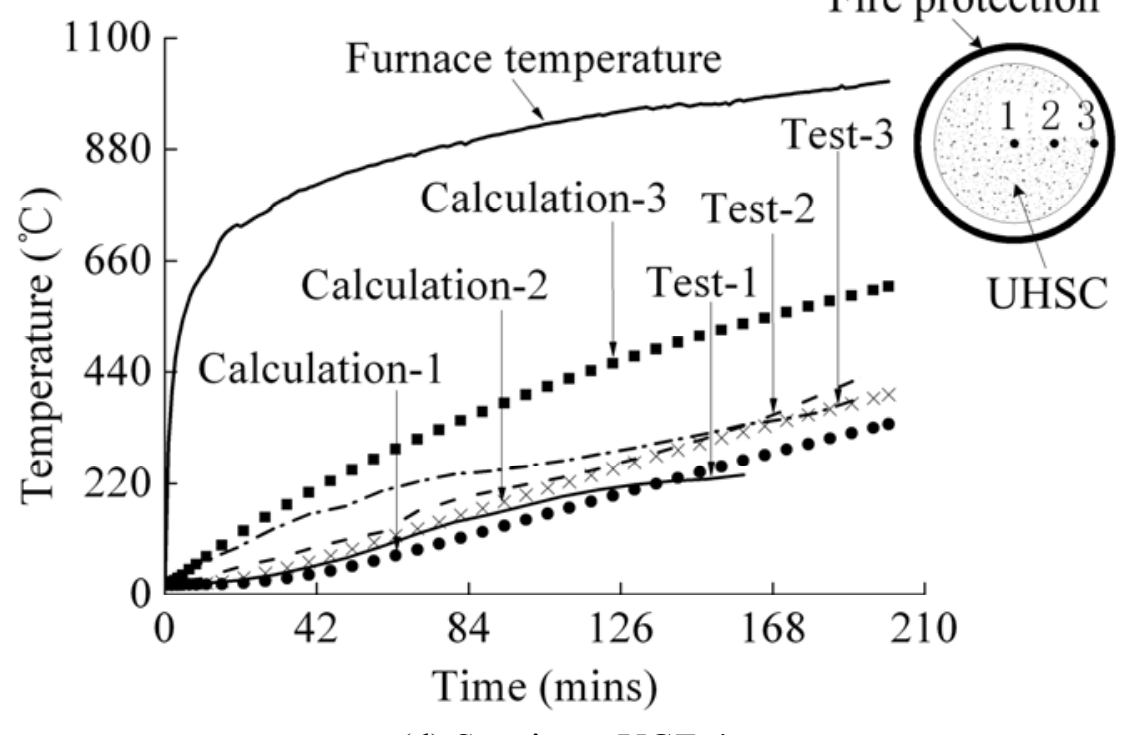

(d) Specimen UCZ-4 


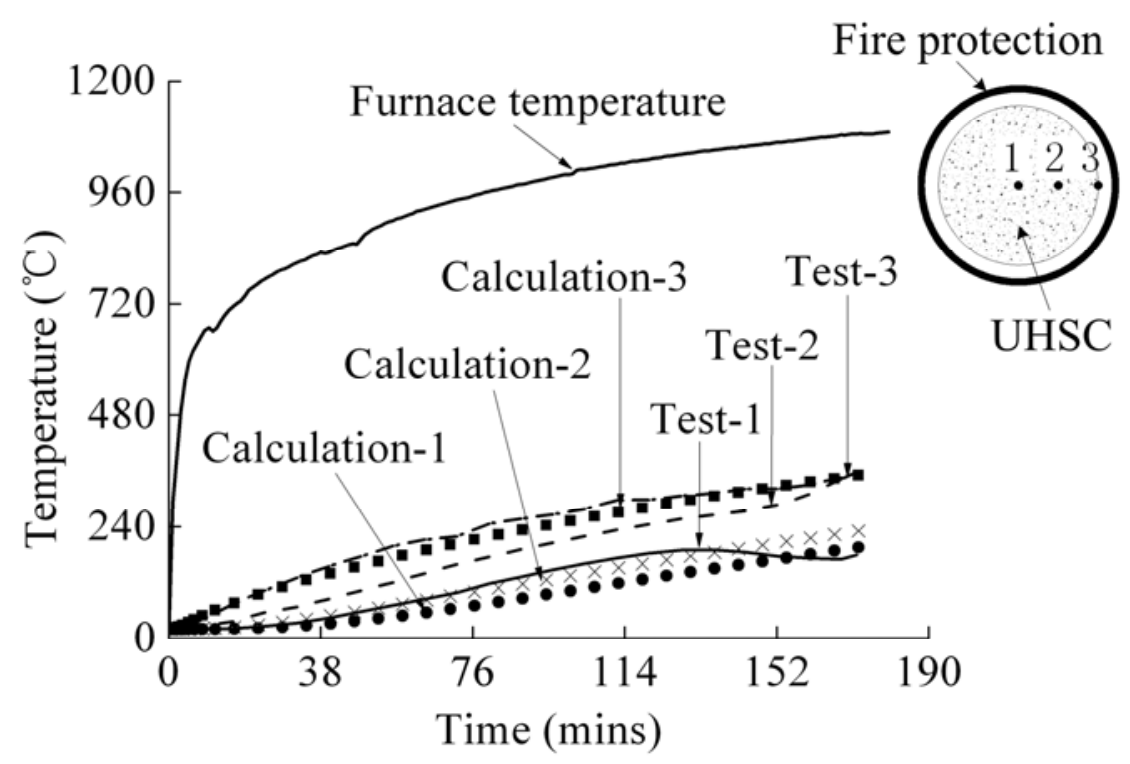

(e) Specimen UCZ-5

Figure 3. Comparison between the Predicted and Measured Temperatures for Specimens UCZ-1 5

\section{MECHANICAL PROPERTIES AT ELEVATED TEMPERATURE}

\subsection{Ultra-High Strength Concrete (UHSC)}

There is limited information on the mechanical properties of UHSC at elevated temperature. Xiong [19] conducted tests to evaluate the elastic modulus and compressive strength of the UHSC at elevated temperatures. In the tests, cylinder specimens with diameter $=100 \mathrm{~mm}$ and height $=200$ $\mathrm{mm}$ were prepared. The specimens were heated in a furnace without pre-loading at a rate of $5^{\circ} \mathrm{C} / \mathrm{min}$ until the target temperature was reached. Dosage of $0.1 \%$ polypropylene in volume was added into UHSC in case of spalling during heating. The target temperatures ranged between $100^{\circ} \mathrm{C}$ to $800^{\circ} \mathrm{C}$ at an increment of $100^{\circ} \mathrm{C}$. Once the target temperature was reached, it was held for 4 hours to ensure that the temperature was uniformly distributed inside the test specimen. Finally, the specimen was subjected to compression until failure with displacement rate $0.4 \mathrm{~mm} / \mathrm{min}$ during loading. A typical stress-strain relationship of UHSC at elevated for specimen UCZ-1 is shown in Figure 4. The reduction factors of the elastic modulus and compressive strength for specimens are shown in Tables 2 and 3, respectively. The test data were fitted into the stress-strain models in Eurocode 2 [23] as follow:

$$
\sigma=\frac{3 \varepsilon f_{\mathrm{c}, \theta}}{\varepsilon_{\mathrm{cl}, \theta}\left[2+\left(\frac{\varepsilon}{\varepsilon_{\mathrm{cl}, \theta}}\right)^{3}\right]} \quad 0 \leq \varepsilon \leq \varepsilon_{\mathrm{cul}, \theta}
$$

Where, $f_{\mathrm{c}, \theta}$ is the compressive strength, $\varepsilon_{\mathrm{c} 1, \theta}$ is the strain corresponding to $f_{\mathrm{c}, \theta}, \varepsilon_{\mathrm{cu} 1, \theta}$ is the strain for defining range of the descending branch. 
Table 2. Reduction of Secant Modulus for UHSC at Elevated Temperature

\begin{tabular}{ccccccc}
\hline $\begin{array}{c}\text { Temperature } \\
\left({ }^{\circ} \mathrm{C}\right)\end{array}$ & $\begin{array}{c}\text { UCZ-1 } \\
(\mathrm{MPa})\end{array}$ & $\begin{array}{c}\text { UCZ-2 } \\
(\mathrm{MPa})\end{array}$ & $\begin{array}{c}\text { UCZ-3 } \\
(\mathrm{MPa})\end{array}$ & $\begin{array}{c}\text { UCZ-4 } \\
(\mathrm{MPa})\end{array}$ & $\begin{array}{c}\text { UCZ-5 } \\
(\mathrm{MPa})\end{array}$ & $\begin{array}{c}\text { Mean } \\
\text { reduction }\end{array}$ \\
\hline 20 & $9.57 \times 10^{4}$ & $9.98 \times 10^{4}$ & $9.74 \times 10^{4}$ & $1.08 \times 10^{5}$ & $1.07 \times 10^{5}$ & 1.00 \\
100 & $7.94 \times 10^{4}$ & $8.28 \times 10^{4}$ & $8.08 \times 10^{4}$ & $8.96 \times 10^{4}$ & $8.88 \times 10^{4}$ & 0.83 \\
200 & $8.61 \times 10^{4}$ & $8.98 \times 10^{4}$ & $8.77 \times 10^{4}$ & $9.72 \times 10^{4}$ & $9.63 \times 10^{4}$ & 0.90 \\
300 & $7.18 \times 10^{4}$ & $7.49 \times 10^{4}$ & $7.31 \times 10^{4}$ & $8.10 \times 10^{4}$ & $8.03 \times 10^{4}$ & 0.75 \\
400 & $5.26 \times 10^{4}$ & $5.49 \times 10^{4}$ & $5.36 \times 10^{4}$ & $5.94 \times 10^{4}$ & $5.89 \times 10^{4}$ & 0.55 \\
500 & $4.31 \times 10^{4}$ & $4.49 \times 10^{4}$ & $4.38 \times 10^{4}$ & $4.86 \times 10^{4}$ & $4.82 \times 10^{4}$ & 0.45 \\
600 & $2.87 \times 10^{3}$ & $2.99 \times 10^{3}$ & $2.92 \times 10^{3}$ & $3.24 \times 10^{3}$ & $3.21 \times 10^{3}$ & 0.30 \\
700 & $2.39 \times 10^{3}$ & $2.50 \times 10^{3}$ & $2.44 \times 10^{3}$ & $2.70 \times 10^{3}$ & $2.68 \times 10^{3}$ & 0.25 \\
800 & $2.20 \times 10^{3}$ & $2.30 \times 10^{3}$ & $2.24 \times 10^{3}$ & $2.48 \times 10^{3}$ & $2.46 \times 10^{3}$ & 0.23 \\
\hline
\end{tabular}

Notes: The data were obtained from Xiong's experiments.

Table 3. Reduction of Compressive Strength for UHSC at Elevated Temperature

\begin{tabular}{ccccccc}
\hline $\begin{array}{c}\text { Temperature } \\
\left({ }^{\circ} \mathrm{C}\right)\end{array}$ & $\begin{array}{c}\text { UCZ-1 } \\
(\mathrm{MPa})\end{array}$ & $\begin{array}{c}\text { UCZ-2 } \\
(\mathrm{MPa})\end{array}$ & $\begin{array}{c}\text { UCZ-3 } \\
(\mathrm{MPa})\end{array}$ & $\begin{array}{c}\text { UCZ-4 } \\
(\mathrm{MPa})\end{array}$ & $\begin{array}{c}\text { UCZ-5 } \\
(\mathrm{MPa})\end{array}$ & $\begin{array}{c}\text { Mean } \\
\text { reduction }\end{array}$ \\
\hline 20 & 161 & 168 & 164 & 181 & 180 & 1.00 \\
100 & 125 & 130 & 127 & 140 & 139 & 0.77 \\
200 & 144 & 150 & 147 & 162 & 161 & 0.89 \\
300 & 153 & 159 & 155 & 172 & 171 & 0.95 \\
400 & 135 & 141 & 138 & 152 & 151 & 0.84 \\
500 & 115 & 120 & 117 & 129 & 128 & 0.71 \\
600 & 99 & 103 & 101 & 111 & 111 & 0.61 \\
700 & 81 & 85 & 83 & 91 & 91 & 0.50 \\
800 & 48 & 50 & 49 & 54 & 54 & 0.30 \\
\hline
\end{tabular}

Notes: The data were obtained from Xiong's experiments.

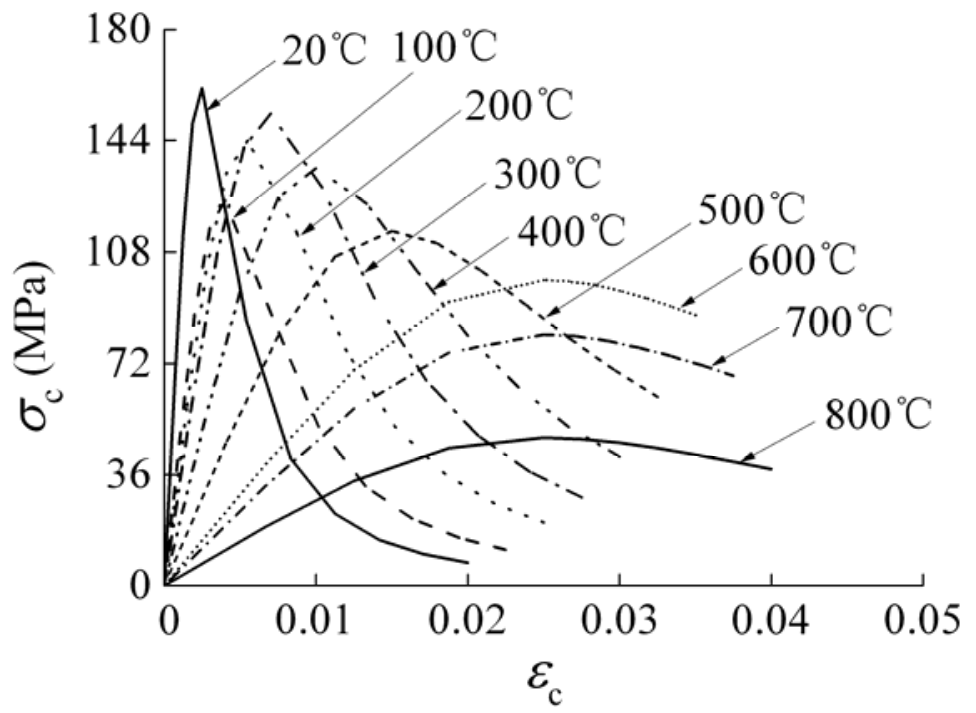

Figure 4. Stress-strain Relationship for UHSC of UCZ-1 at Various Temperatures

Spalling was not observed during heating of all specimens. As shown in Table 2, for the elastic modulus of UHSC at elevated temperature, an unusual deterioration and recovery were observed at the temperature range of $100^{\circ} \mathrm{C} \sim 200^{\circ} \mathrm{C}$. For compressive strength of UHSC at elevated temperature, an unusual deterioration was observed at the temperature $100^{\circ} \mathrm{C}$, which was shown in Table 3 . 
However, with temperature increased range of $100^{\circ} \mathrm{C} \sim 300^{\circ} \mathrm{C}$, the strength was partly recovered. At $800^{\circ} \mathrm{C}$, the strength was only about $30 \%$ of that at room temperature.

Seen from Figure 4, the peak stress decreases sharply at $100^{\circ} \mathrm{C}$ and recovery was observed at the temperature range of $100^{\circ} \mathrm{C} \sim 300^{\circ} \mathrm{C}$, which is the same as the compressive strength. The stress decreases sharply after the peak stress at temperature range of $20^{\circ} \mathrm{C} \sim 300^{\circ} \mathrm{C}$, but it decreases gently at temperature range of $400^{\circ} \mathrm{C} \sim 800^{\circ} \mathrm{C}$.

\subsection{Steel}

Eurocode 3 [25] provides the equations to describe the elastic modulus and effective strength of steel at elevated temperature. The reduction factors of elastic modulus, yield strength and the relationship of stress and strain at elevated temperature given in Eurocode 3:1-2 [25] are adopted for the numerical analysis.

\section{FIRE RESISTANCE OF UHSCFT COLUMNS}

\subsection{Eurocode 4 Approach}

According to the simplified method in Eurocode 4 [24], the plastic resistance of the concrete filled circular cross-section may be calculated as:

$$
N_{\mathrm{pl}, \mathrm{Rk}}=A_{\mathrm{a}} f_{\mathrm{y}}+A_{\mathrm{c}} f_{\mathrm{ck}}
$$

if $\bar{\lambda}>0.5$. Otherwise, concrete confinement effect may be considered in calculating the cross section plastic resistance as:

$$
N_{\mathrm{pl}, \mathrm{Rk}}=\eta_{\mathrm{a}} A_{\mathrm{a}} f_{\mathrm{y}}+A_{\mathrm{c}} f_{\mathrm{ck}}\left(1+\eta_{\mathrm{c}} \frac{t_{\mathrm{s}}}{d} \frac{f_{\mathrm{y}}}{f_{\mathrm{ck}}}\right)
$$

Where $A_{\mathrm{a}}$ and $A_{\mathrm{c}}$ are cross-sectional areas of the steel section, concrete core respectively. $\eta_{\mathrm{a}}$ and $\eta_{\mathrm{c}}$ are the steel strength reduction and the concrete strength enhancement factor, respectively. $f_{\mathrm{y}}$ and $f_{\mathrm{ck}}$ are characteristic strengths of structural steel and concrete core respectively. $t_{\mathrm{s}}$ is the wall thickness of steel tube, $d$ is the overall diameter of composite column.

To account for overall buckling of the column, the reduction factor $\chi$ is given in terms of the relative slenderness $\bar{\lambda}$ and the corresponding buckling curve as follow,

$$
\chi=\left(\Phi+\sqrt{\Phi^{2}-\bar{\lambda}^{2}}\right)^{-1} \leq 1.0
$$

where, $\Phi=0.5\left[1+\alpha(\bar{\lambda}-0.2)+\bar{\lambda}^{2}\right]$ and

$$
\bar{\lambda}=\sqrt{\frac{N_{\mathrm{pl}, \mathrm{Rk}}}{N_{\mathrm{cr}}}}
$$

$\alpha$ is an imperfection factor corresponding to the appropriate buckling curve. For concrete filled tubes, buckling curve "a" and $\alpha=0.21$ are adopted if the reinforcement ratio does not exceed $3 \%$. 
In the tests, there is no reinforcement in the UHSCFT columns, therefore $\alpha=0.21$ is adopted herein. For comparison with test results, $N_{\mathrm{pl}, \mathrm{Rk}}$ calculated from Eq. 2 or Eq. 3 should be based on characteristic strengths. $N_{\mathrm{cr}}=\pi^{2}(E I)_{\mathrm{eff}} / l_{\mathrm{e}}^{2}$ is the Euler buckling load of the composite column, and $(E I)_{\text {eff }}=E_{\mathrm{a}} I_{\mathrm{a}}+0.6 E_{\mathrm{cm}} I_{\mathrm{c}}$ is the effective flexural stiffness of the composite cross-section, where $E_{\mathrm{a}}$ is the modulus of elasticity of the structural steel and $E_{\mathrm{cm}}$ is the secant modulus of elasticity of concrete. $I_{\mathrm{s}}$ and $I_{\mathrm{c}}$ are the second moments of area of the structural steel section and the uncracked concrete section respectively.

The characteristic buckling resistance of composite column subject to compression is given as

$$
N_{\mathrm{b}, \mathrm{Rk}}=\chi N_{\mathrm{pl}, \mathrm{Rk}}
$$

\subsection{Thermal-Mechanical Analysis}

During the thermal stress analysis, the element mesh remains the same as the temperature field analysis without fire protection. But the element type is changed from heat transfer element to thermal mechanical element.

In the thermal-mechanical analysis, 8-node brick element (C3D8R) is adopted for the UHSC core and 4-node shell element (S4R) for steel tube. The finite element meshes for the column cross-section is shown in Figure 5a. The column is simply supported at both ends with the boundary conditions as shown in Figure 5a.

The observed failure mode of specimen UCZ-3 and the predicted failure mode from FEM are shown in Figures 5b-c. The temperatures, stresses and strains at the centre of each element are assumed to be representative of those of the entire element. Furthermore, it is assumed that the steel and the concrete had the same temperature, t, at the interface (Song et al. [26]; Wang et al. [27]). Mesh convergence studies have been performed to study the sensitivity of the mesh size on the predicted results. An optimized mesh size of $20 \mathrm{~mm}$ (length):20 mm (width):60 mm (depth) for the part of specimen inside furnace, $20 \mathrm{~mm}$ (length):20 mm (width): $100 \mathrm{~mm}$ (depth) for the rest part of specimen outside furnace was selected to ensure that the predicted results are within $2 \%$ error.

The time-dependent thermal-mechanical analysis was performed using the ABAQUS, a general nonlinear finite element program. The column is assumed to have an initial bow imperfection approximating a half-sine curve of mid-height magnitude of Length//1000. This member imperfection has been adopted based on the first buckling mode shape of pin-ended column subject to axial compression.

The value of friction coefficient $\mu=0.2$ to 0.5 is assumed between the steel tube and concrete core [28]. Sensitivity study on the friction coefficient has been carried out based on specimen UCZ-3. The result is shown in Figure 6. According to the analysis results, the influence of friction coefficient on the fire resistance of composite column is insignificant when the value is between 0.3 and 0.5 . The use of $\mu=0.2$ causes convergence problem near the failure temperature. The use $\mu=0.3$ is most appropriate as the predicted displacement-time curve is closer to the test result. Finally, $\mu=0.3$ is selected for the friction coefficient in longitudinal direction. As for the friction coefficient in the tangential direction, this factor has little effect on the fire response of composite columns according to the previous research done in Espinos et al. [28] and thus $\mu=0.3$ is assumed. A "Hard" contact formulation is used in the transverse direction normal to the concrete core surface to capture the contact pressure between the steel and concrete surfaces when they are in contact and allow for separation when the two surfaces move in different directions. 

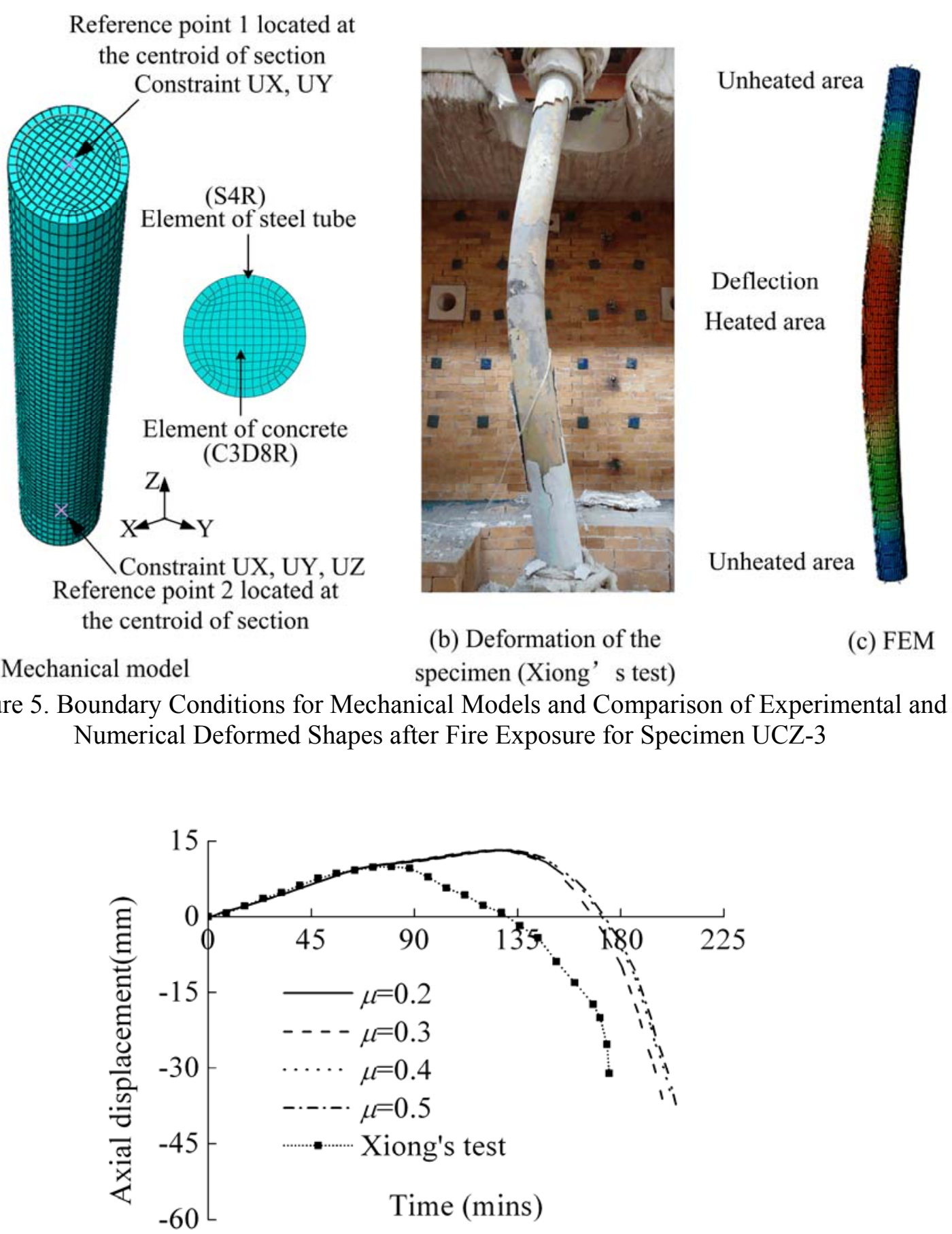

Figure 6. Comparison of Test and Predicted Results with Different Friction Coefficients

The period of time that a column can maintain the compressive load when subject to an ISO-834 Standard fire is determined [20]. For a column member subject to compression, failure occurs when either of the following two criteria is reached:

(1) The axial deformation of the column reaches $0.01 \mathrm{~L} \mathrm{~mm}$, or

(2) The axial deformation velocity exceeds $0.003 \mathrm{~L} \mathrm{~mm} / \mathrm{min}$, where $\mathrm{L}$ is the fire exposed length of column in millimeter. 
The results from the numerical analyses and tests are shown in Figure 7(a)-(e), and the comparisons are given in Table 4. The error of predicting the fire resistance of the concrete filled tubular columns, as compared to the test results, is within $15 \%$. The error is considered to be reasonable and the numerical model will be used for parametric analyses in the subsequent sections.

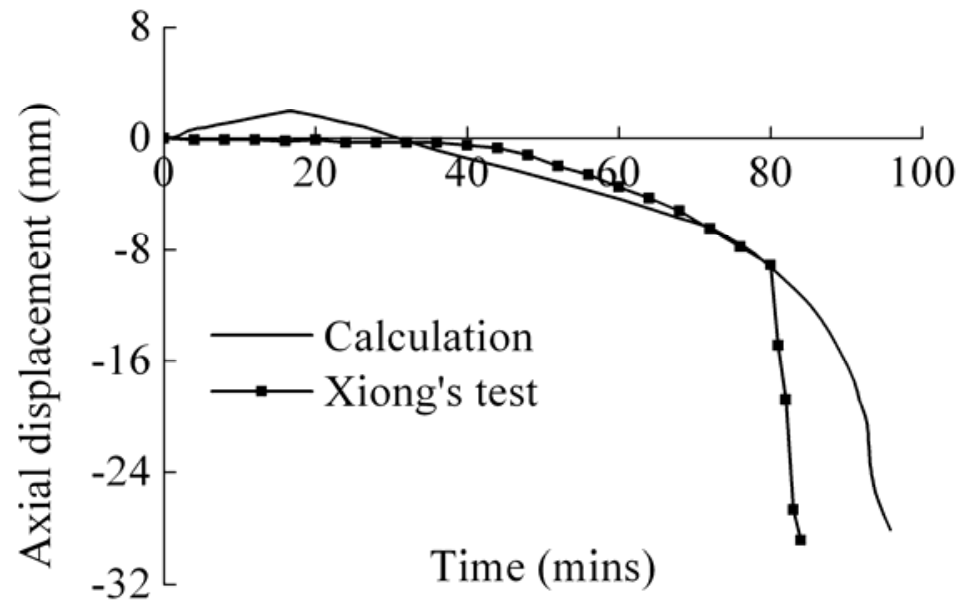

(a) Specimen UCZ-1

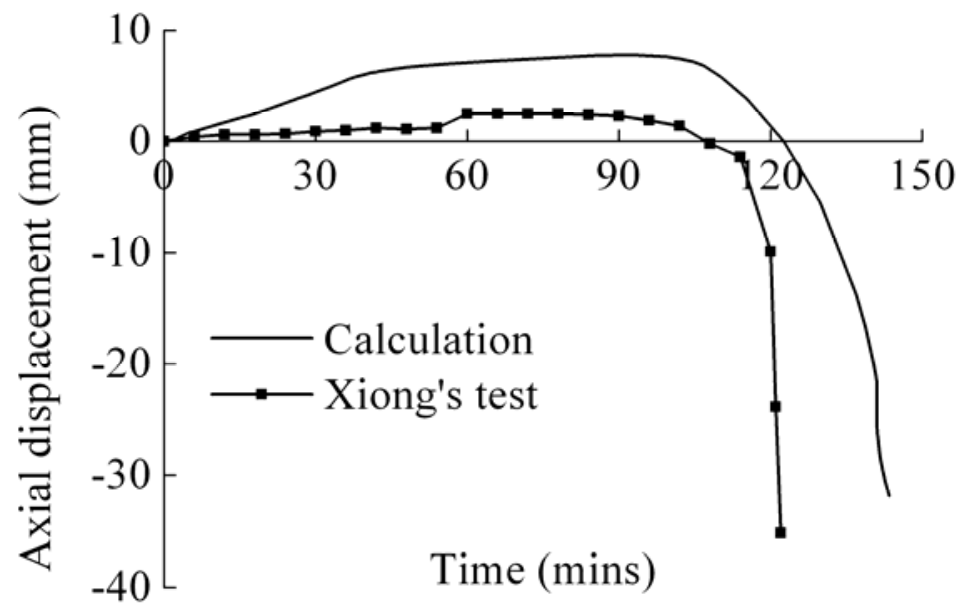

(b) Specimen UCZ-2

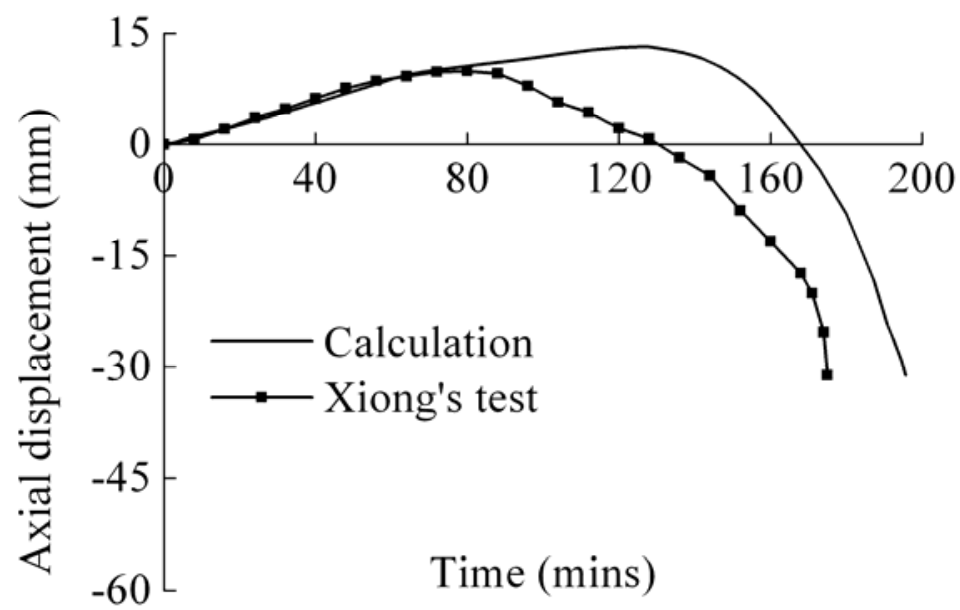

(c) Specimen UCZ-3 


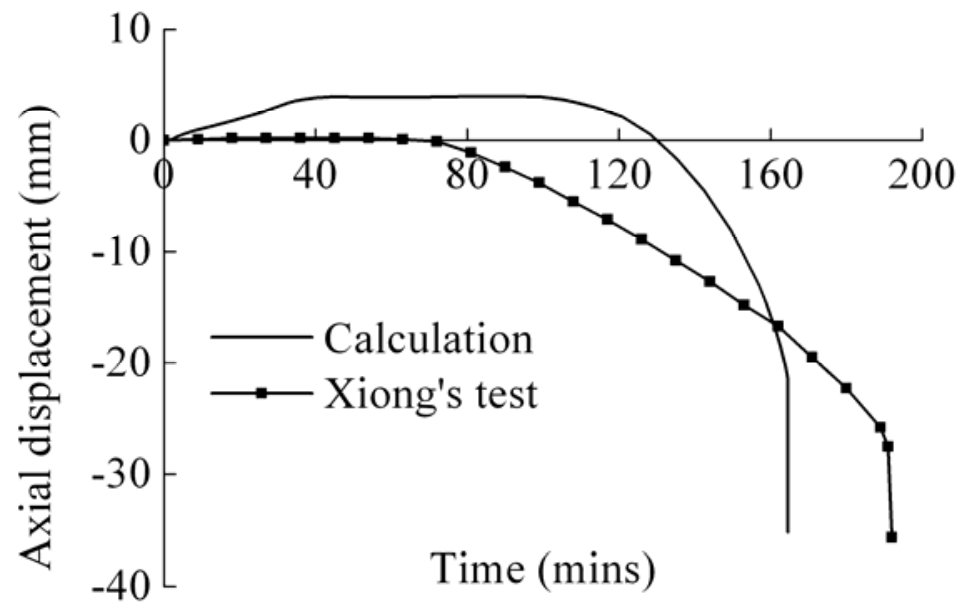

(d) Specimen UCZ-4

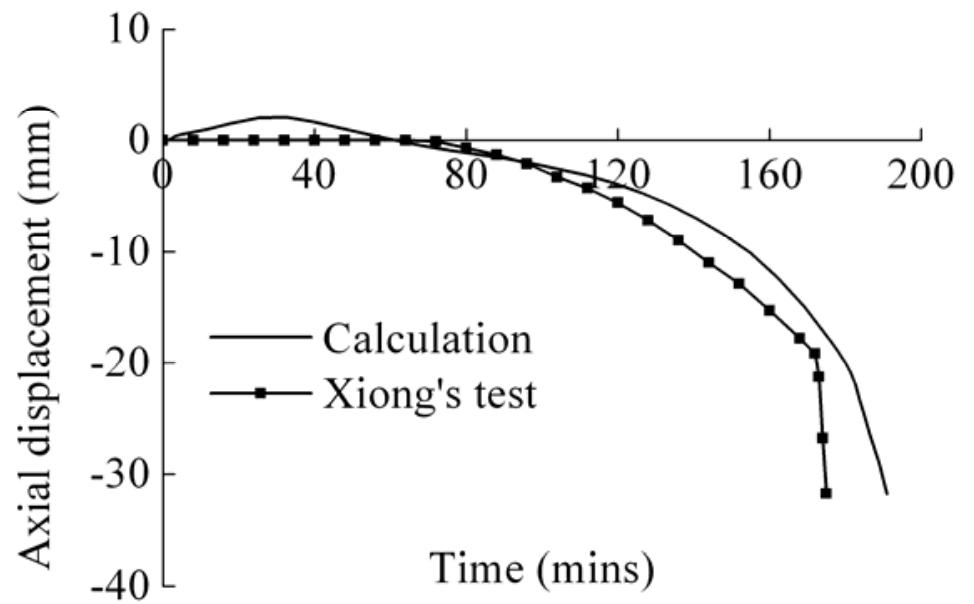

(e) Specimen UCZ-5

Figure 7. Comparison of Fire Resistance between the Calculation Results and Experimental Results (Xiong [19])

Table 4. Comparison of Fire Resistance Time between Predicted and Experimental Results

\begin{tabular}{cccccc}
\hline Specimen & $t_{\mathrm{p}}(\mathrm{mm})$ & $\beta^{*}$ & $\begin{array}{c}\mathrm{FR}^{*} \text {-Predicted } \\
(\mathrm{min})\end{array}$ & $\begin{array}{c}\text { FR }^{*} \text {-Experiment } \\
(\min )\end{array}$ & $\begin{array}{c}\text { Error } \\
(\%)\end{array}$ \\
\hline UCZ-1 & 5.9 & 0.63 & 97 & 84 & 13 \\
UCZ-2 & 6.4 & 0.59 & 140 & 122 & 15 \\
UCZ-3 & 8.1 & 0.47 & 195 & 175 & 11 \\
UCZ-4 & 6.8 & 0.53 & 165 & 191 & -14 \\
UCZ-5 & 8.6 & 0.56 & 191 & 175 & 9 \\
\hline
\end{tabular}

Note: "FR" is the fire resistance time. " $\beta$ " is load ratio.

\section{PARAMETRIC STUDY ON FIRE RESISTANCE}

Parametric analysis is carried out on circular concrete filled tube section with diameter $D$ and tube thickness $t_{\mathrm{s}}$, length $L$, and is subjected to fire all round. The column is assumed to have an initial bow imperfection approximating a half-sine curve of mid-height magnitude of Length//1000. The 
column ends are assumed to be simply supported and it is subjected to axial compression. Same failure criteria as described in section 4 are assumed in calculating the fire resistance of the UHSCFT column. The load acting on the column is $0.5 N_{\mathrm{b}, \mathrm{Ek}}$ in which $N_{\mathrm{b}, \mathrm{Ek}}$ is the characteristic buckling resistance of the member at ambient temperature based on Eurocode 4 [Error! Bookmark not defined.] prediction.

The parameters that influence the fire resistance of concrete filled tubes are studied using the finite element model established in Section 4. These parameters include fire protection thickness, load ratio $\beta$, strengths of the concrete and steel, relative slenderness ratio $\bar{\lambda}$ steel contribution ratio ( $\delta=A_{\mathrm{a}} f_{\mathrm{y}} /\left(A_{\mathrm{a}} f_{\mathrm{y}}+A_{\mathrm{c}} f_{\mathrm{c}}\right)$, where the $A_{\mathrm{a}}$ and $A_{\mathrm{c}}$ are the cross-sectional areas of steel tube and concrete core, respectively). The results are shown in Figs. 8-14.

\subsection{Effect of Fire Protection Thickness}

As shown in Figures 8(a) \& (b), the thickness of fire protection has a great influence on the fire resistance of the composite column. The fire protection thickness, $t_{\mathrm{p}}$, is varied from $2 \mathrm{~mm}$ to $12 \mathrm{~mm}$, with the thickness of the steel tube $t_{\mathrm{s}}$, steel contribution ratio $\delta$ and relative slenderness ratio $\bar{\lambda}$ unchanged. The relationship between the increase of fire protection and the fire resistance is almost linear and this information can be easily used for structural-fire design of concrete filled tube. In the beginning of heating, thermal axial expansion is more serious for columns with thinner fire protection. As the time of fire exposure is getting longer, the column deflects laterally and eventually leads to axial shortening until failure occurs with run-away deflection. Figure $8 \mathrm{~b}$ shows the relationship between the fire protection thickness and the fire resistant time of the column. The increase of fire resistance time is about 18 minutes per unit thickness of fire protection in $\mathrm{mm}$. The minimum fire protection thickness is about $5 \mathrm{~mm}$ to attain a 2-hour ISO standard fire rating.

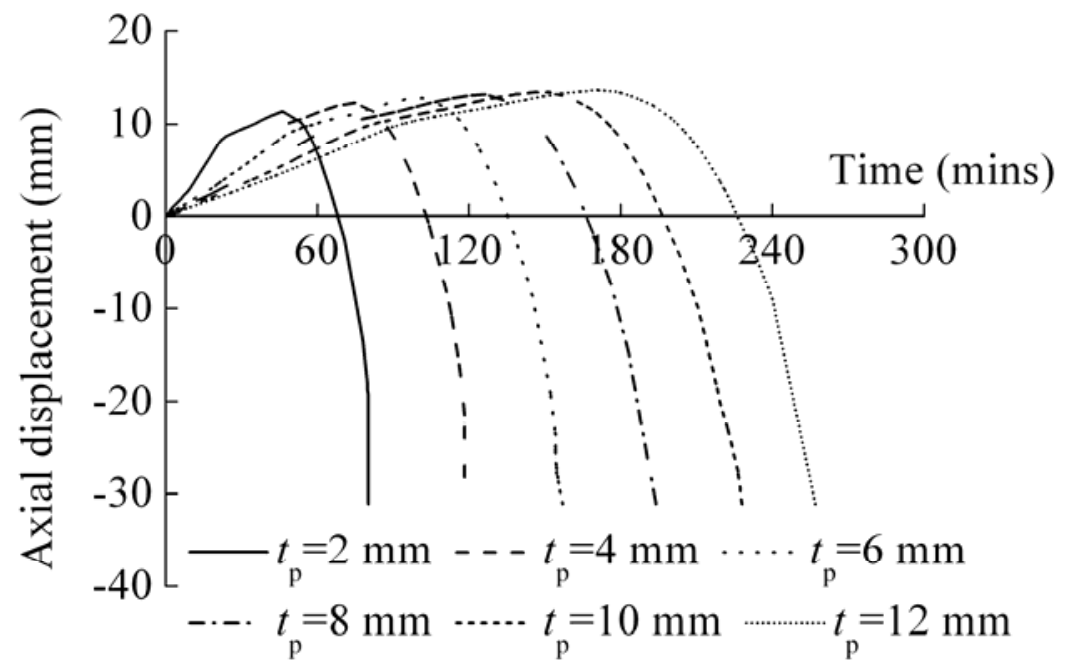

(a) 


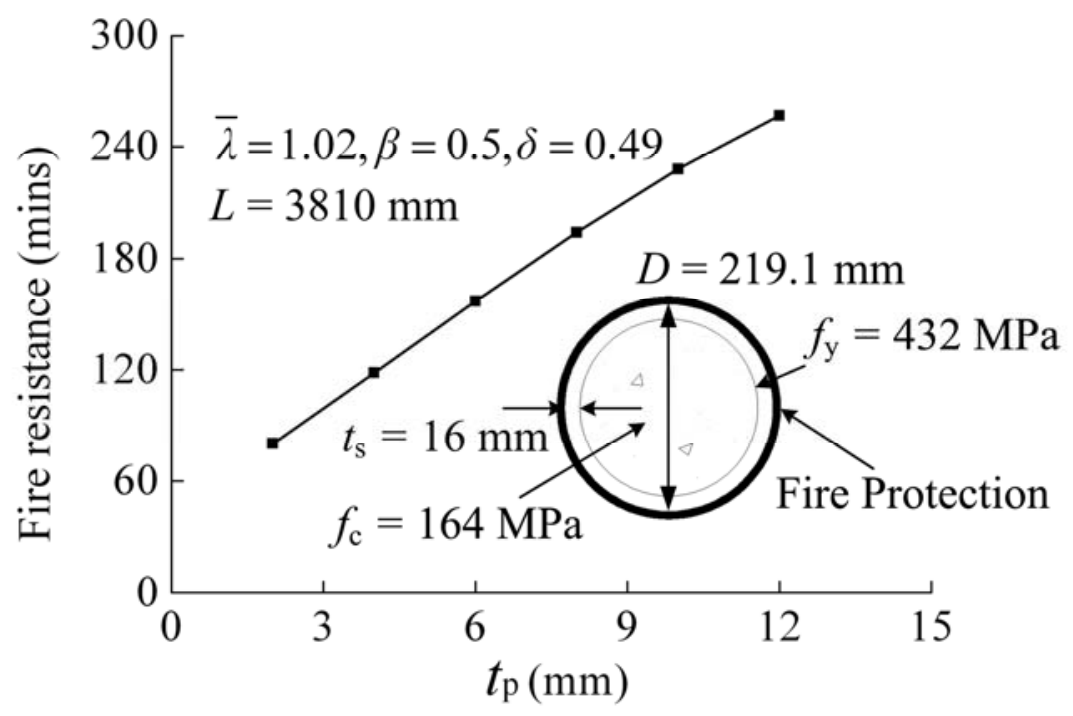

(b)

Figure 8. Relationship between Fire Protection Thickness ( $\mathrm{mm}$ ) and Fire Resistant Time (mins)

\subsection{Effect of Load Ratio}

Figure 9(a) shows the effects of load ratio on the fire resistance of the composite column, with the thickness of fire protection $t_{\mathrm{p}}$, load ratio $\beta$, steel contribution ratio $\delta$ and relative slenderness ratio $\bar{\lambda}$ unchanged. Figure 9(b) shows that the relationship between the fire resistant time and load ratio is nonlinear. With the load ratio increasing, the fire resistance of the column decreases rapidly. It is obvious to see that the upward expansion is larger for columns subject to smaller load ratio. As expected, the fire resistance rating of the composite column decreased with an increase of applied load. For example, the fire resistance decreases $15 \%$ while the load ratio $\beta$ changes from 0.3 to 0.4 , but this trend becomes mild with the value of load ratio increasing. The fire resistance time decreases only $7 \%$ while the load ratio $\beta$ varies from 0.8 to 0.9 .

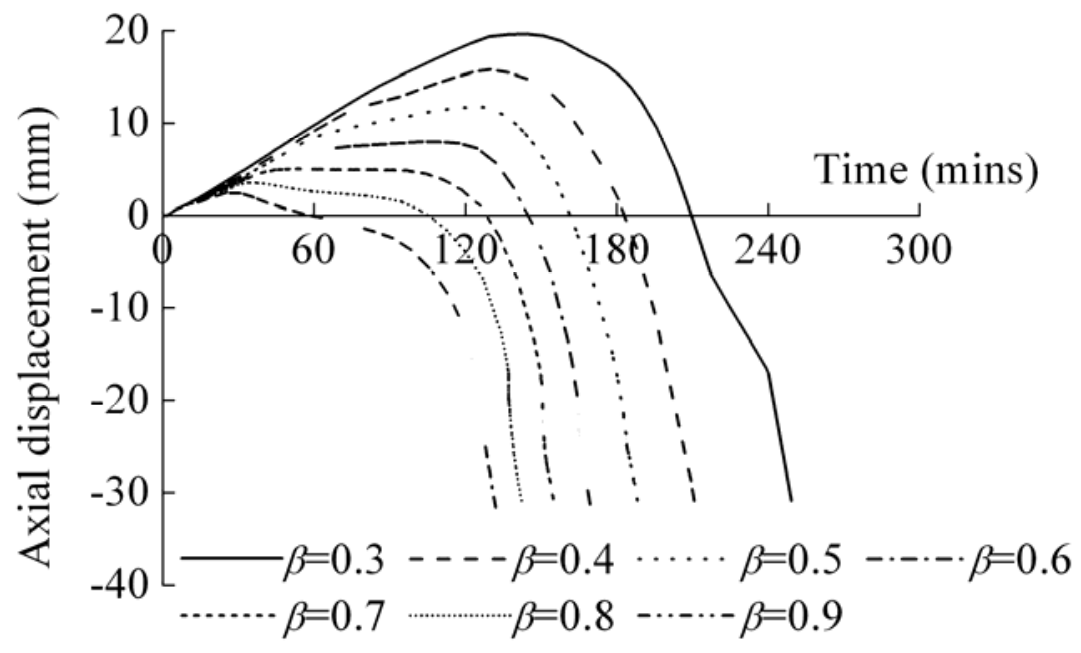

(a) 


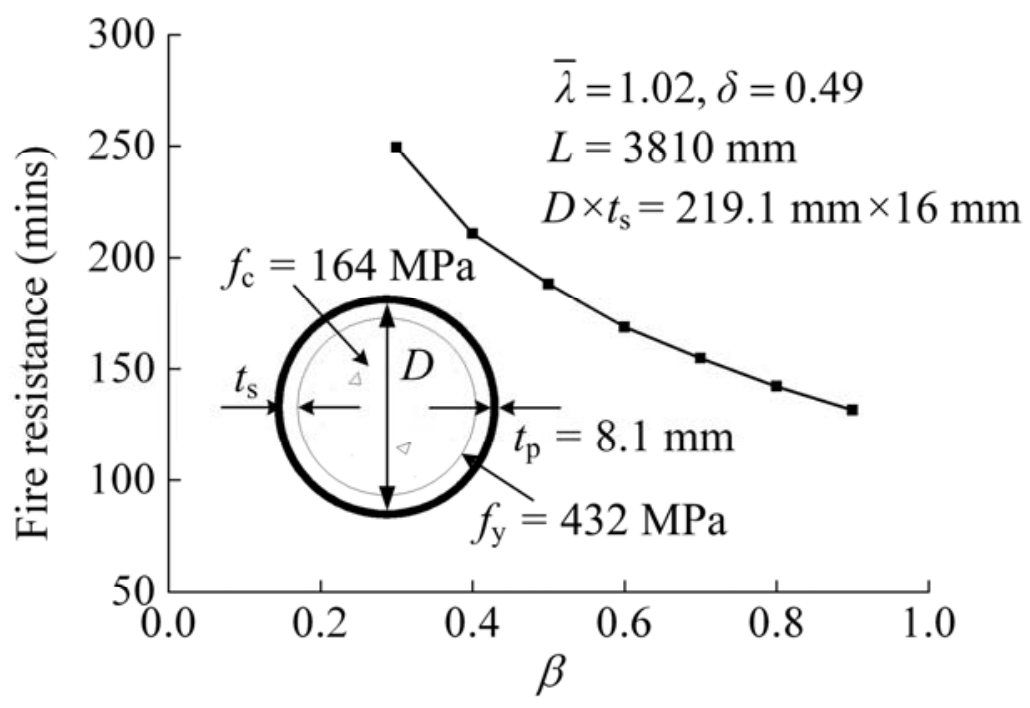

(b)

Figure 9. Relationship between Load Ratio and Fire Resistance Time (mins)

\subsection{Effect of Concrete Strength}

Figure 10(a) shows the effects of concrete strength on fire resistance of composite column, with the thickness of fire protection $t_{\mathrm{p}}$, load ratio $\beta$ and strength of steel $f_{\mathrm{y}}$ unchanged. Figure $10(\mathrm{~b})$ plots the fire resistant time with respected to the concrete strength. It shows that the influence of concrete strength on the fire resistance of the composite column is insignificant. The fire resistance improves slightly and almost linearly with an increase of the concrete strength. For example, the fire resistance increases only $1 \%$, while the concrete strength varies from $f_{\mathrm{c}}=140 \mathrm{MPa}$ to $f_{\mathrm{c}}=160 \mathrm{MPa}$, about $14 \%$ increment.

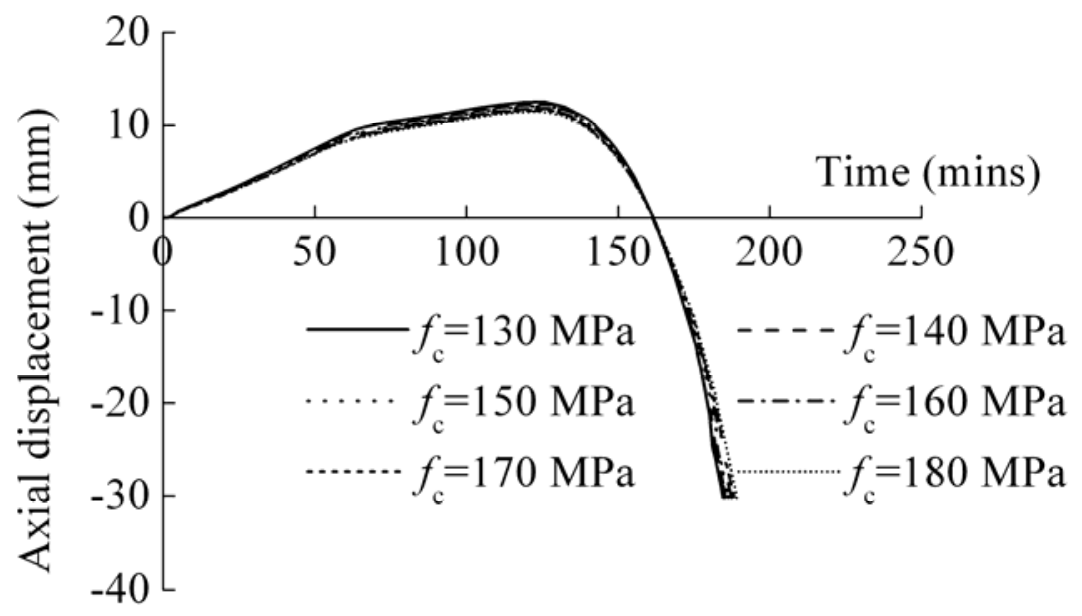




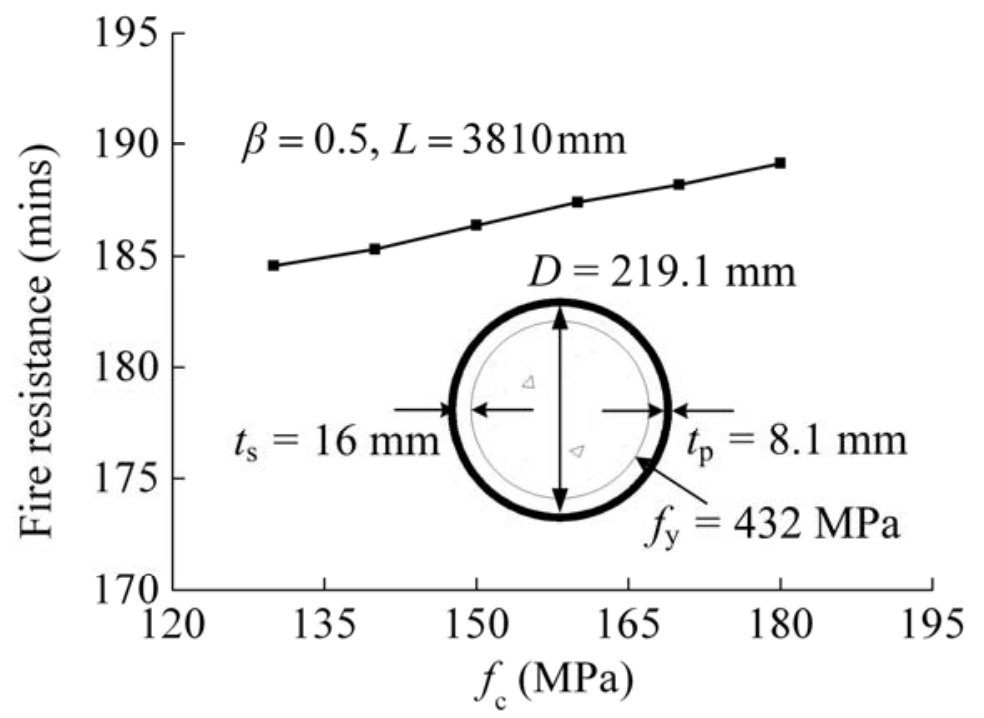

(b)

Figure 10. Relationship between Concrete Strength (MPa) and Fire Resistance Time (mins)

\subsection{Effect of Steel Strength}

Figure 11(a) shows the effects of steel strength on fire resistance of composite column, with the thickness of fire protection $t_{\mathrm{p}}$, load ratio $\beta$ and strength of concrete $f_{\mathrm{c}}$ unchanged. Figure 11(b) shows the fire resistant time with respected to the steel strength. It is observed that the steel strength has a moderate influence on the fire resistance of the composite column. The fire resistance improves slightly but linearly as the steel strength increases. For example, the fire resistance increases only $2 \%$, while the concrete strength varies from $f_{\mathrm{y}}=355 \mathrm{MPa}$ to $f_{\mathrm{y}}=420 \mathrm{MPa}$, about $18 \%$ increment.

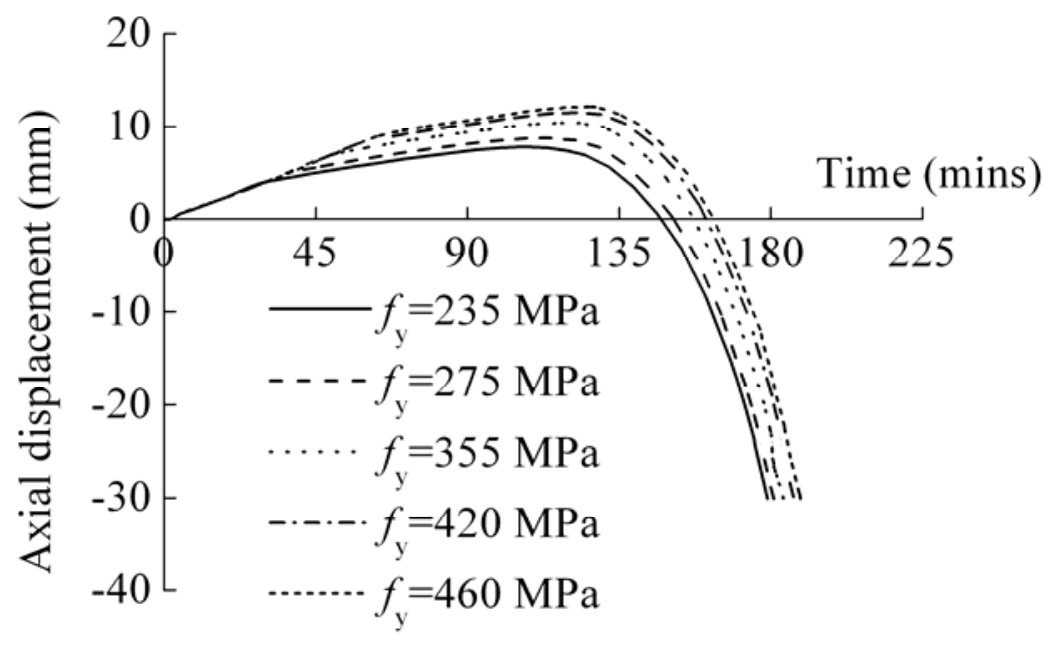

(a) 


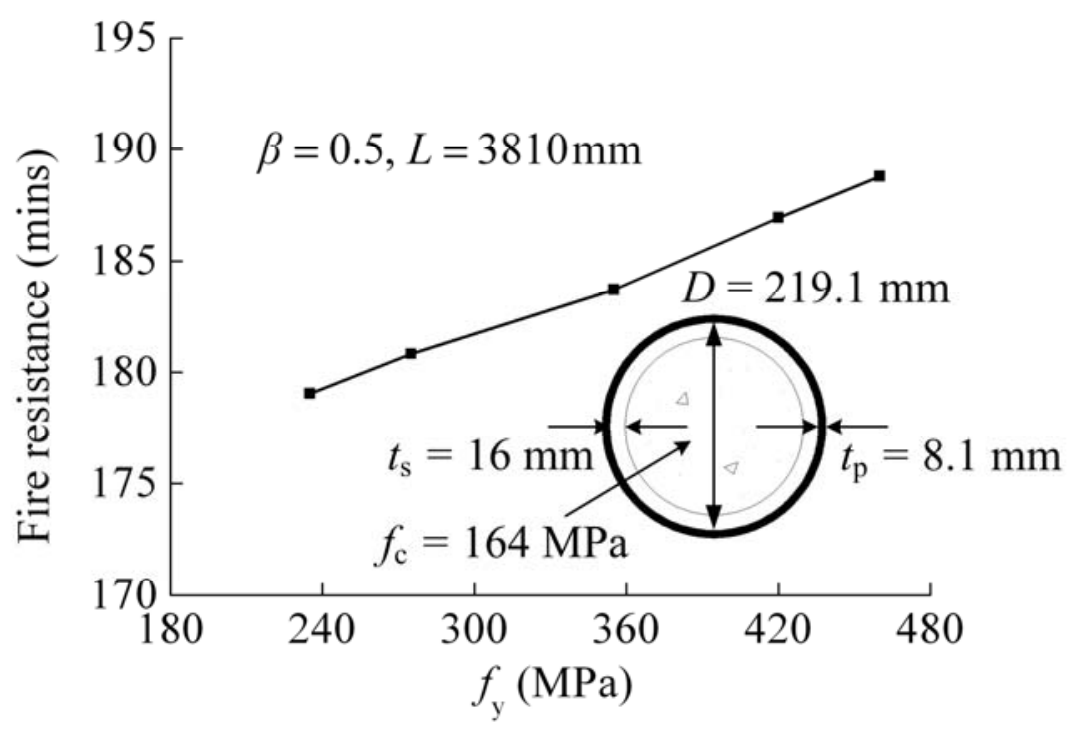

(b)

Figure 11. Relationship between Steel Strength (MPa) and Fire Resistance Time (mins)

\subsection{Effect of Steel Contribution Ratio}

The fire resistance of UHSCFT column increases somewhat with the increase of steel contribution ratio as shown in Figs. 12(a) \& (b), with the thickness of fire protection $t_{\mathrm{p}}$, load ratio $\beta$, strength of concrete $f_{\mathrm{c}}$ and strength of steel $f_{\mathrm{y}}$ unchanged. The fire resistance of the columns improves slightly with the increase of steel contribution ratio. With the steel ratio varied from 0.17 to 0.57 , the fire resistance increases 5 minutes, in other words, only $3 \%$ increment.

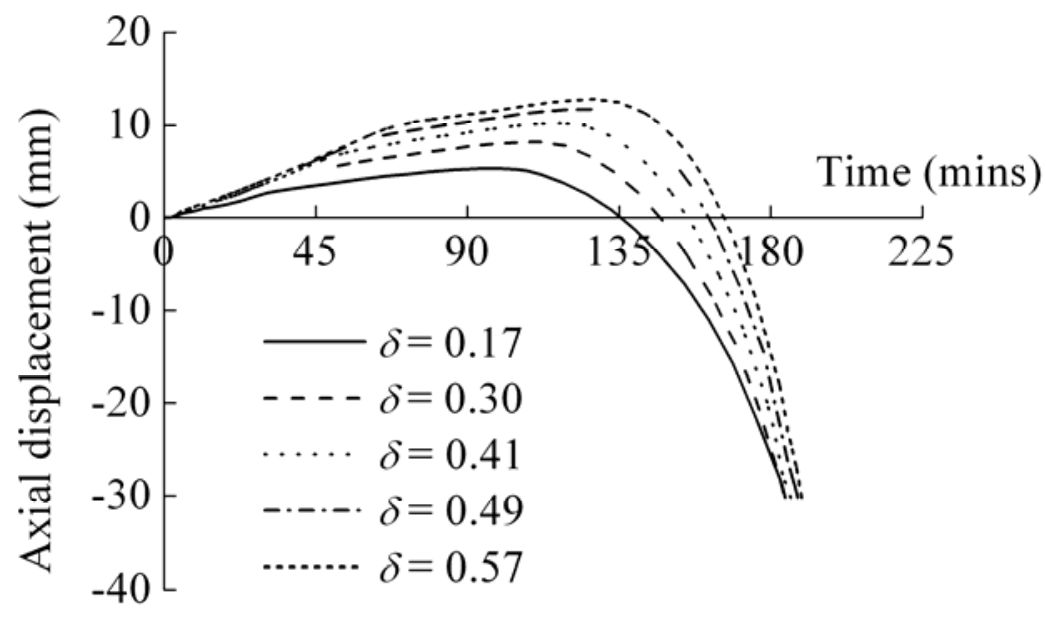

(a) 


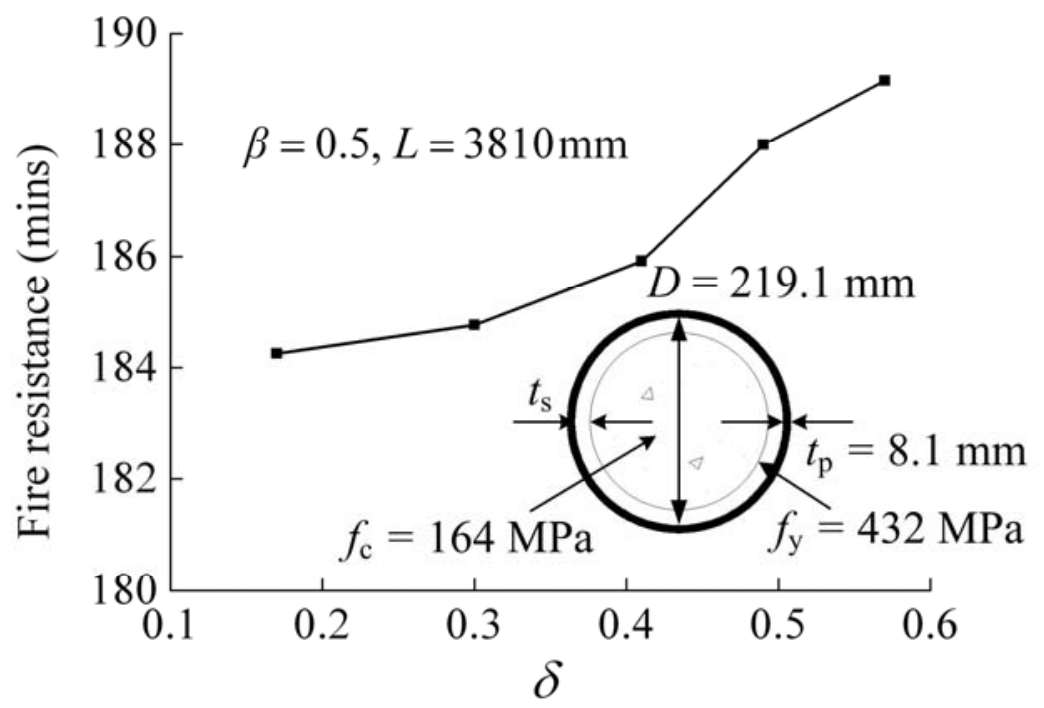

(b)

Figure 12. Relationship between Steel Contribution Ratio and Fire Resistance Time (mins)

\subsection{Effect of Relative Slenderness Ratio}

It is well known that the slenderness plays an important role in the buckling resistance of a column in compression. In order to study the effect of the column slenderness on fire resistance of UHSCFT column, the relative slenderness ratio $\bar{\lambda}$ varies from 0.34 to 1.36 by changing the column length $L$ from $1270 \mathrm{~mm}$ to $5080 \mathrm{~mm}$ with an initial imperfection of $L / 1000$. Figure 13 shows that the relative slenderness ratio has a significant influence on the fire resistance of composite column, with the thickness of fire protection $t_{\mathrm{p}}$, load ratio $\beta$ and steel contribution ratio $\delta$ unchanged. The fire resistance decreases significantly with the increase of the relative slenderness ratio. This can be attributed to larger second-order moment due to axial force acting on higher lateral deflection of the column with larger relative slenderness ratio.

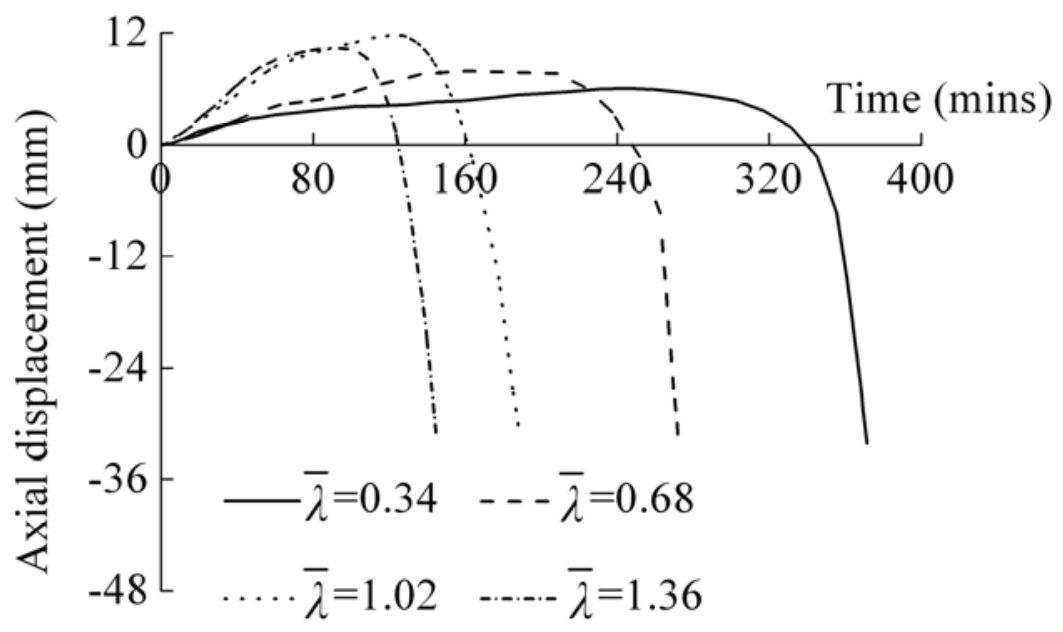

(a) 


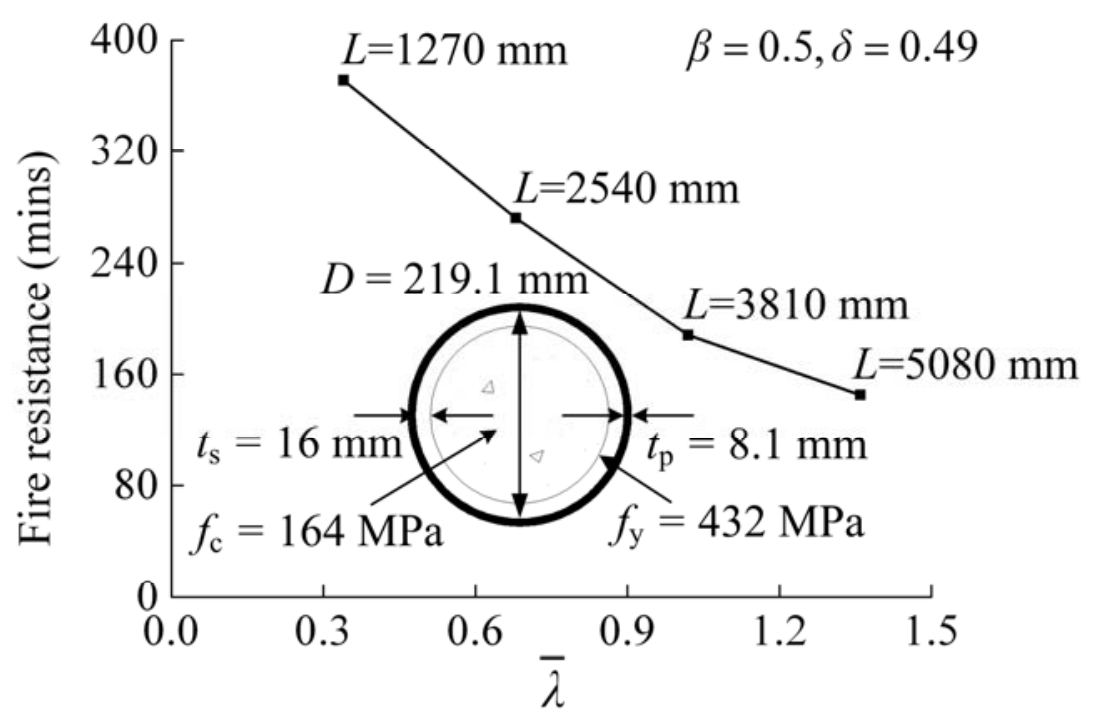

(b)

Figure 13. Relationship between Relative Slenderness Ratio and Fire Resistance Time (mins)

\subsection{Effect of the Steel Section Diameter}

The effects of outside diameter $(D)$ of the composite column on the fire resistance is shown in Figure $14(\mathrm{a}) \&(\mathrm{~b})$, with the thickness of fire protection $t_{\mathrm{p}}\left(t_{\mathrm{p}}=8.1 \mathrm{~mm}\right)$, thickness of the steel tube $t_{\mathrm{s}}$ ( $t_{\mathrm{s}}=16 \mathrm{~mm}$ ), $\beta=0.5$ and $\bar{\lambda}=1.02$ of the column unchanged. The fire resistance improves obviously with the diameter increasing. This can be attributed to the longer time it takes the larger diameter column to reach temperatures at which it lost its strength so that the column can no longer support the applied load. The curves in this figure indicate that the column outside diameter, which is a measure for the column section size, has a very great influence on the fire resistance of the column. For example, with the steel section diameter varied from $219.1 \mathrm{~mm}$ to $438.2 \mathrm{~mm}$, the fire resistance increases 84 minutes, in other words, $45 \%$ increment.

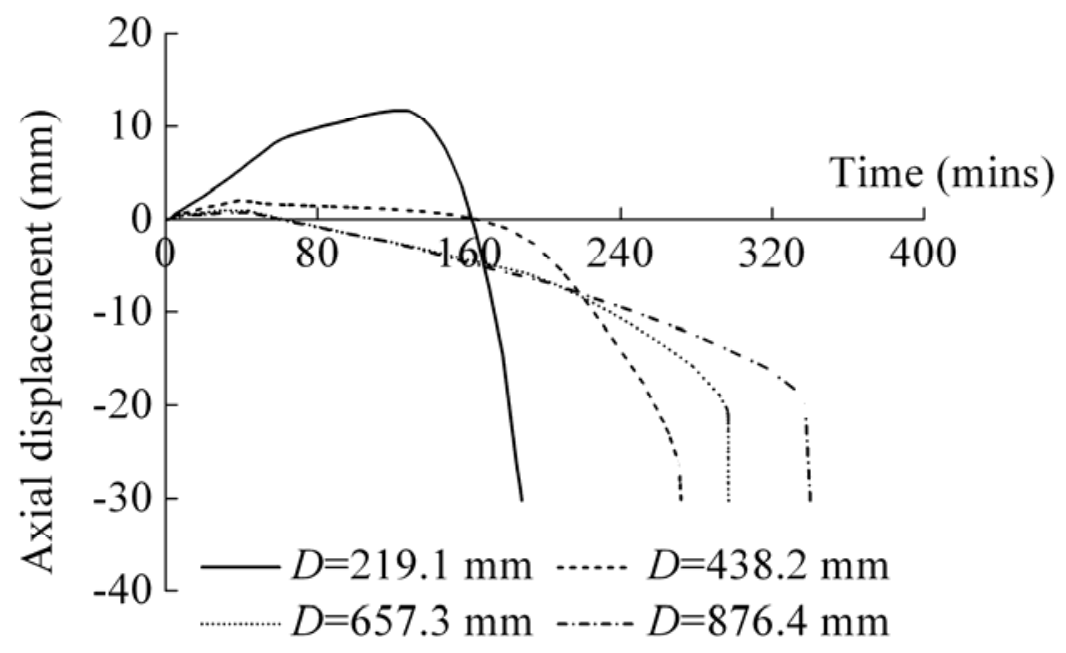

(a) 


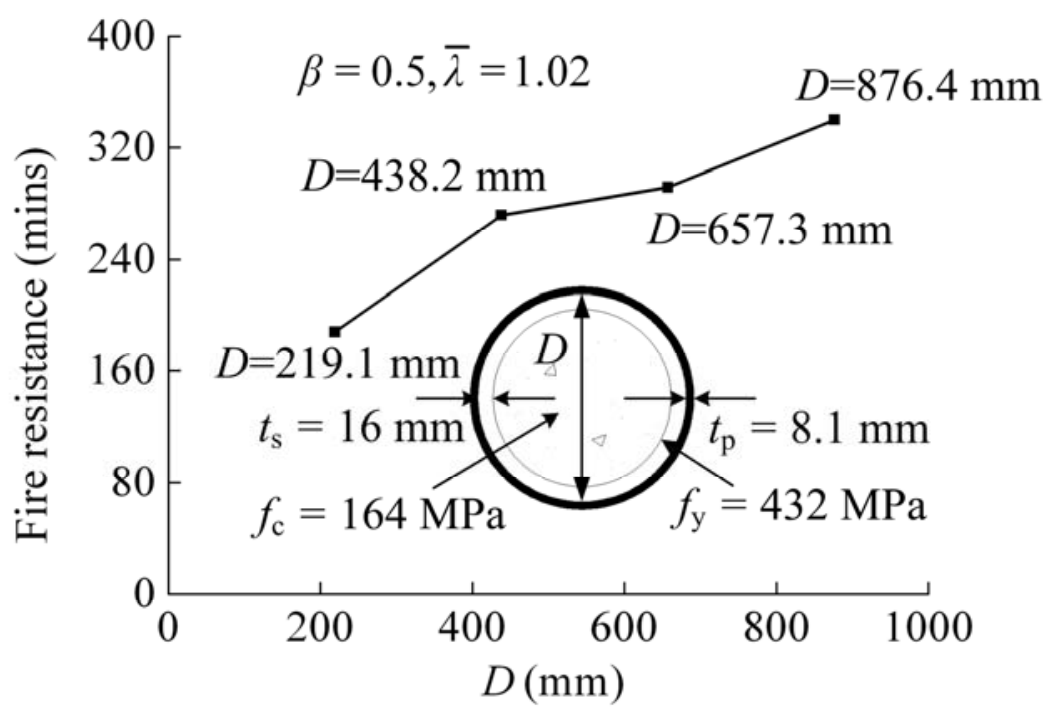

(b)

Figure 14. Relationship between Steel Section Diameter and Fire Resistance Time (mins)

Based on the analysis results, the thickness of protection, load ratio, relative slenderness ratio and the steel section diameter have significant effects on the fire resistance of UHSCFT columns subject to axial load. Whereas, the other parameters, such as the steel contribution ratio, the strength of concrete and steel have only moderate effects on the fire resistance of the columns.

\section{CONCLUSION}

This paper proposes a nonlinear finite element model to predict the temperature field and perform thermal-mechanical analysis of UHSCFT columns. The accuracy of the model has been established by comparing the predicted results with the fire test results. The established numerical model is then used to perform parametric analyses to investigate the load deformation behavior and fire resistance of steel tubular members infilled with ultra-high strength concrete.

By protecting the steel tube surface with a layer of low thermal conductivity material, UHSCFT columns can achieve adequate fire resistance, taking advantage of the heat capacity of the inner concrete core for to conduct heat away from the steel tube. The analyses show that the temperature of the steel tube and the ultra-high strength concrete core increased slowly with the increase of fire protection layer while the temperature of the furnace rose shapely close to ISO standard fire especially at the beginning of 10 minutes. The temperature distribution in the cross section, fire resistance and axial-load deformation of the UHSCFT columns calculated from the proposed numerical model were in reasonable agreement with the experimental results.

It was observed that the failure of UHSCFT columns occurred suddenly, showing brittle behavior. The fire resistance decreases significantly with the increase of the column relative slenderness ratio. The thickness of protection, load ratio, relative slenderness ratio and the diameter of steel section were found to have significant effects on the fire resistance of UHSCFT columns under axial compression. Whereas the steel contribution ratio, the strength of concrete, and strength of steel have only moderate effects on the fire resistance of the columns, if other parameters were kept the same. 
The relationship between the increase of fire protection and the fire resistance is almost linear and this information provides useful guidance for structural-fire design of concrete filled tube. The effects of concrete strength and steel strength on fire resistance are nearly linear too, although this influence on fire resistance is limited. The curves in Figure 9 and Figure 13 roughly show that the fire resistance decreases more than quadratically with the relative slenderness ratio and load ratio. The effect of steel section diameter on fire resistance should be also considered as useful guidance for structural-fire design of concrete filled tube.

\section{ACKNOWLEDGEMENTS}

The research work is supported by the National Key Technology R\&D Program of China during the 12th Five-Year Plan Period (No. 2012BAJ13B01). The financial support is highly appreciated.

\section{REFERENCES}

[1] Lie, T.T. and Chabot, M., "Experimental Studies on the Fire Resistance of Hollow Steel Columns Filled with Plain Concrete", Internal Report No.611, Institute for Research in Construction, National Research Council of Canada, Ottawa, Canada, 1992

[2] Tao, Z., Wang, Z.B., Han, L.H. and Uy, B., "Fire Performance of Concrete-Filled Steel Tubular Columns Strengthened by CFRP”, Steel and Composite Structures, 2011, Vol. 11, No. 4, pp. 307-324.

[3] Zha, X.X., Li, X.L., Wang, N. and Wan, C.Y., "Study on Axial Compression Bearing Capacity of Reinforced Concrete Filled Steel Tube Members", Advanced Steel Construction, 2016, Vol. 12, No. 2, pp. 94-108.

[4] Jamaluddin, N., Lam, D., Dai, X.H. and Ye., J., "An Experimental Study on Elliptical Concrete Filled Columns under Axial Compression”, Journal of Constructional Steel Research, 2013, Vol. 87, pp. 6-16.

[5] Kang, W.H., Tao, Z. and Uy, B., "Design Strength of Concrete-Filled Steel Columns", Advanced Steel Construction, 2015, Vol. 11, No. 2, pp. 165-184.

[6] Xiao, J.Z., Li, Z.W., Xie, Q.H. and Shen, L.M., "Effect of Strain Rate on Compressive Behaviour of High-Strength Concrete after Exposure to Elevated Temperatures", Fire Safety Journal, 2016, Vol. 83, pp. 25-37.

[7] Han, L.H., Li, W. and Bjorhovde, R., "Developments and Advanced Applications of Concrete-Filled Steel Tubular (CFST) Structures: Members", Journal of Construction Steel Research, 2014, Vol.100, No.5, pp. 211-228.

[8] Fong, M., Chan, S.L. and Uy, B., "Advanced Design for Trusses of Steel and Concrete-Filled Tubular Sections”, Engineering Structures, 2011, Vol. 33, No. 12, pp.3162-3171.

[9] $\mathrm{Xu}, \mathrm{Y} ., \mathrm{Fu}, \mathrm{Y}$., Zhang, Y. and Zhao, X., "Fire Resistance of Crisscross Concrete Filled Steel Tube Core Columns in The Different Axial Compression”, Advanced Materials Research, 2011, Vol. 163-167, pp. 157-160.

[10] Wang, K. and Young, B., "Fire Resistance of Concrete-Filled High Strength Steel Tubular Columns", Thin-Walled Structures, 2013, Vol. 71, pp. 46-56.

[11] Yang, H., Liu, F.Q. and Gardner, L., "Post-Fire Behaviour of Slender Reinforced Concrete Columns Confined by Circular Steel Tubes", Thin-Walled Structures, 2015, Vol. 87, pp. 12-29.

[12] Liew, J.Y.R. and Xiong, M.X., "Design Guide for Concrete Filled Tubular Members with High Strength Materials to Eurocode 4", Research Publishing Services, 2015, ISBN-13: 978-981-09-3267-1; ISBN-10: 981-09-3267-7. 32-37. 
[13] Li, G.C., Yang, Z.J., Lang, Y.and Fang, C., "Behavior of High Strength Concrete Filled Square Steel Tubular Columns with Inner CFRP Circular Tube Under Bi-Axial Eccentric Loading", Advanced Steel Construction, 2013, Vol. 9, No. 3, pp. 231-246.

[14] Lee, J.H., Sohn, Y.S., and Lee, S.H., "Fire Resistance of Hybrid Fibre-Reinforced, Ultrahigh-Strength Concrete Columns with Compressive Strength from 120 to $200 \mathrm{MPa}$ ", Magazine of Concrete Research, 2012, Vol. 64, No. 6, pp. 539-550.

[15] Xiong, M.X. and Liew, J.Y.R., "Spalling Behavior and Residual Resistance of Fibre Reinforced Ultra-High Performance Concrete after Elevated Temperatures", Materiales de Construcción, 2015, Vol. 65, No.320, pp. 1-10.

[16] Liew J.Y.R, Xiong, M.X. and Xiong, D.X, "Design of Concrete Filled Tubular Beam-Columns with High Strength Steel and Concrete", Structures, 2016, Vol 8, Part 2, pp. 213-226.

[17] Liew, J.Y.R., Xiong, M.X. and Xiong, D.X., "Design of High Strength Concrete Filled Tubular Columns for Tall Buildings", International Journal of High-Rise Buildings, 2014, Vol. 3, No. 3, pp. 1-7.

[18] Liew, J.Y.R., Xiong M.X. and Tran C.T., "Design Guide for Concrete Filled Tubular Members with High Strength Materials - An Extension of Eurocode 4 Method to C90/105 Concrete and S550 Steel", Building and Construction Authority of Singapore, 2015, pp. 23-40, 69-72.

[19] Xiong, M.X., "Fire Resistance of Ultra-High Strength Concrete Filled Steel Tubular Columns", PhD Dissertation, 2013, National University of Singapore, Singapore.

[20] ISO-834-1, "Fire-Resistance Tests-Elements of Building Construction Part1: General Requirements", International Standard ISO-834, Geneva, 1999.

[21] Yu, M., Zha, X. X., Ye, J. Q. and Li, Y., "Fire Responses and Resistance of Concrete-Filled Steel Tubular Frame Structures", International Journal of Structural Stability and Dynamics, 2010, Vol. 10, No. 2, pp. 253-271.

[22] Dai, X.H. and Lam, D., "Shape Effect on the Behaviour of Axially Loaded Concrete Filled Steel Tubular Stub Columns at Elevated Temperature", Journal of Constructional Steel Research, 2012, Vol. 73, pp. 117-127.

[23] ECS, Eurocode 2, "Design of Concrete Structures-Part 1-2, General Rules-Structural Fire Design”, EN 1992-1-2, European Committee for Standardization, 2004.

[24] ECS, Eurocode 4, "Design of Composite Steel and Concrete Structures-Part 1-2, General Rules-Structural Fire Design”, EN 1994-1-2, European Committee for Standardization, 2005.

[25] ECS, Eurocode 3, "Design of Steel Structures-Part 1-2, General Rules-Structural Fire Design", EN 1993-1-2, European Committee for Standardization, 2005.

[26] Song, T. Y., Han, L. H. and Uy, B., "Performance of CFST Column to Steel Beam Joints Subjected to Simulated Fire Including The Cooling Phase", Journal of Constructional Steel Research, 2010, Vol. 66, pp. 591-604.

[27] Wang, R.L., Zhang, C. and Li, G.Q., "Simple Approach for Performance-Based Fire Safety Design of Circular CFT Columns in Large Enclosure", Advanced Steel Construction, 2016, Vol. 12, No. 1, pp. 32-43.

[28] Espinos, A., Romero, M.L. and Hospitaler, A., "Advanced Model for Predicting The Fire Response of Concrete Filled Tubular Columns", Journal of Constructional Steel Research, 2010, Vol. 66, No. 8-9, pp. 1030-1046. 